\title{
PHYSICAL CHARACTERIZATION OF RADIOACTIVE SLUDGES IN SELECTED MELTON VALLEY AND EVAPORATOR FACILITY STORAGE TANKS
}
R. N. Ceo*
M. B. Scars
J. T. Shor

*Experimental work described in this report was performed by R. N. Ceo whilc he was a member of the Analytical Chemistry Division. His present affiliation is the Y-12 Plant, Oak Ridge, TN.

Date Published - October 1990

\author{
Prepared for the \\ Office of Defense Waste and Environmental Restoration \\ (Activity No. GF 7301010 ) \\ Prepared by the \\ OAK RIDGE NATIONAL LABORATORY \\ Oak Ridge, Tennessce 37831 \\ operated by \\ MARTTN MARIETTA ENERGY SYSTEMS, INC. \\ for the \\ U.S. DEPARTMENT OF ENERGY \\ under contract DE-AC05-84OR21400
}




\section{CONTENTS}

LIST OF FIGURES $\ldots \ldots \ldots \ldots \ldots \ldots \ldots \ldots \ldots \ldots \ldots \ldots \ldots \ldots \ldots$

LIST OF TABLES $\ldots \ldots \ldots \ldots \ldots \ldots \ldots \ldots \ldots \ldots \ldots \ldots \ldots \ldots \ldots \ldots$

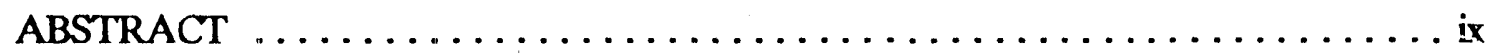

1. INTRODUCTION $\ldots \ldots \ldots \ldots \ldots \ldots \ldots \ldots \ldots \ldots \ldots \ldots \ldots \ldots \ldots \ldots \ldots \ldots$

2. SAMPLE HANDLING AND ANALYSIS PLAN $\ldots \ldots \ldots \ldots \ldots \ldots \ldots$

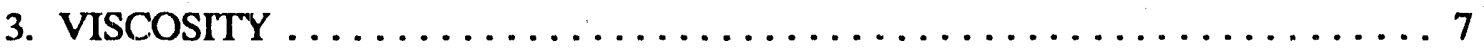

4. DENSITY AND SOLIDS MEASUREMENTS $\ldots \ldots \ldots \ldots \ldots \ldots \ldots \ldots$

5. SEDIMENTATION RATE $\ldots \ldots \ldots \ldots \ldots \ldots \ldots \ldots \ldots \ldots \ldots \ldots \ldots$

6. PARTICLE SIZE . . . . . . . . . . . . . . . . . . . 27

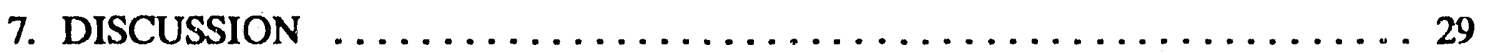

8. ACKNOWLEGMENTS $\ldots \ldots \ldots \ldots \ldots \ldots \ldots \ldots \ldots \ldots \ldots \ldots \ldots \ldots$

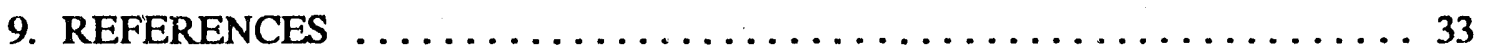

APPENDIX A. LISTING OF PHYSICAL PROPERTIES DATA . . . . . . . 35

APPENDIX B. CALCULATIONAL MODEL USED TO DETERMINE DENSITY AND SOLIDS VALUES $\ldots \ldots \ldots \ldots \ldots \ldots \ldots \ldots$ 


\section{LIST OF FIGURES}

Figure Pagc

1 Flow chart for physical measurements $\ldots \ldots \ldots \ldots \ldots \ldots \ldots \ldots$

2 Rheological properties of neat sludge sample $\mathrm{W} 21-\mathrm{S} 1 \ldots \ldots \ldots \ldots$

3 Rheological properties of sludge sample W21-S1 diluted $1: 1 \ldots \ldots \ldots \ldots$

4 Rheological properties of sludge sample W23-S1 diluted $1: 1 \ldots \ldots \ldots \ldots 11$

5 Rheological properties of neat sludge sample W26-S3 . . . . . . . 12

6 Rheological properties of sludge sample W26-S3 diluted $1: 1 \ldots \ldots \ldots \ldots$

7 Rheological properties of neat sludge sample W28-S1 . . . . . . . . 14

8 Rheological properties of sludge sample W28-S1 diluted $1: 1 \ldots \ldots \ldots \ldots$

9 Rheological properties of sludge sample W28-S1 diluted $1: 3 \ldots \ldots \ldots$

10 Typical sedimentation rate curve $\ldots \ldots \ldots \ldots \ldots \ldots \ldots \ldots \ldots \ldots . \ldots \ldots$

11 Typical concentration dependence of sedimentation rate $\ldots \ldots \ldots \ldots 25$ 


\section{LIST OF TABLES}

Table

$\underline{\text { Page }}$

1 Information for sludge samples $\ldots \ldots \ldots \ldots \ldots \ldots \ldots \ldots \ldots \ldots \ldots$

2 Viscosities of selected waste tank samples $\ldots \ldots \ldots \ldots \ldots \ldots \ldots \ldots$

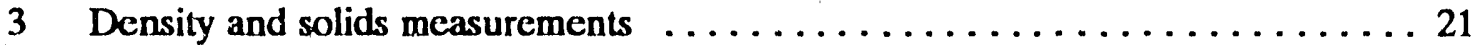

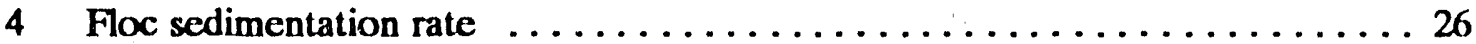

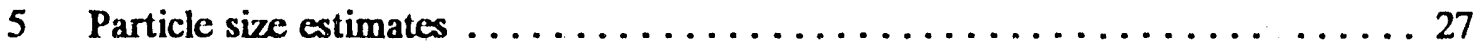

6 Physical properties of selected waste tank samples $\ldots \ldots \ldots \ldots \ldots \ldots \ldots$ 


\begin{abstract}
Physical measurements were performed on typical radioactive sludge samples from selected Melton Valley Storage Tanks (MVSTs) and evaporator facility storage tanks at ORNL. These measurements included viscosity, particle size, density, sedimentation rate, and solids content. The techniques developed during this project are simple and use inexpensive apparatus to assay the range of physical properties spanned by the sample set.

The report provides data in support of (1) the design of the propused Waste Handling and Packaging Plant, and (2) research and development activities in developing waste management alternatives.
\end{abstract}




\title{
PHYSICAL. CHARACTERIZATION OF RADIOACTIVE SLUDGES IN SELECTED MELTON VALLEY AND EVAPORATOR FACILITY STORAGE TANKS
}

\author{
R. N. Ceo \\ M. B. Sears \\ J. T. Shor
}

\section{INTRODUCTION}

The purpose of this study was to determine physical properties of the radioactive sludges in the waste storage tanks at the Oak Ridge National Laboratory (ORNL). Objectives include providing data in support of (1) the design of the proposed Waste Handling and Packaging Plant (WHPP) and (2) research and development (R\&D) activities in developing waste management alternatives. This information is needed to design systems for processing these wastes for disposal. Relevant sludge properties include density, solids content, viscosity, sedimentation rate, and particle size. These characteristics will influence the selection of the technology for removing the sludges from the tanks, as well as the design of the piping, valves, pumps, and drivers for plant process systems.

This report describes the physical characterization of four samples that are typical of sludges in the Melton Valley Storage Tanks (MVSTs) and the storage tanks at the low-level waste (LLW) evaporator service facility in Bethel Valley. Methods used for sampling the tanks and results of the analyses of the wastes for chemical and radiochemical constituents are presented in a related report by Sears et al. ${ }^{1}$

Other research groups at ORNL have performed extensive characterization of the waste's chemical and radiochemical properties; 1,2 however, until this project, no detailed assay of physical properties had been done. These measurements were difficult to make for several reasons, including sample inhomogeneity, mutability of physical characteristics after sampling, the need to make several measurements from the same small samples, and the radiotoxicity of the samples. Several simple methods have been developed to make the necessary physical measurements. The project has provided important information to the plant's designers, and the methods reported here may guide others in making similar measurements. The report also summarizes limitations and sources of error associated with sampling and measurement. 


\section{SAMPLE HANDLING AND ANALYSIS PLAN}

\section{SAMPLE COLLECTION AND HANDLING}

During this project, 21 sludge samples and 22 liquid samples were collected from six of the MVSTs (tanks W-24 through W-28 and W-31) and two of the storage tanks at the evaporator service facility (W-21 and W-23). The collection of the samples and the chemical and radiochemical characterization of the wastes are described in detail in ref. 1. Four sludge samples were selected as a representative set for the physical measurements described in this report based on apparent physical properties and estimated volumes.

A brief summary of the collection and handling of the samples is given in this section (for details, see ref. 1). All of the tanks are located in below-grade concrete vaults, and each is accessed by means of a 7.6-cm (3-in.)-diam pipe that penetrates the tank from the roof of the vault. Liquid samples were pulled by vacuum through Teflon tubing into the sample jars. A bottom-opening soft-sludge sampler was used to collect a core of sludge up to $51 \mathrm{~cm}$ (20 in.) deep. The device consists of a detachable handle assembly and a hollow probe of clear polyvinyl chloride (PVC) pipe $(2.5 \mathrm{~cm} \mathrm{ID)} \mathrm{that} \mathrm{can} \mathrm{be} \mathrm{controlled} \mathrm{from} \mathrm{above} \mathrm{by} \mathrm{the}$ operator. The sludge layer was usually more than $51 \mathrm{~cm}$ deep. Samples were collected at successively lower layers to obtain a vertical profile of the tank contents. After the sludge sample had been collected, the handle was removed and the PVC sample tube was capped, packaged, and transported to the analytical laboratory in a shielded carrier.

Sludge samples were unloaded from the carrier and placed in a hot cell. The samples were allowed to stand overnight in the PVC tubes to allow the solids to settle. The height of the sludge (solids) iayer in the tank was then measured. Any liquid layer over the sludge was removed and the sludge (solids) transferred to a sample jar. The sample was stirred gently, and portions were removed for waste characterization studies. Composite sludge samples representative of a complete vertical core were made up for the chemical and radiochemical analyses. ${ }^{1}$ The composite samples were sonicated to ensure complete mixing. The physical measurements described in this report were conducted on unsonicated samples that had been handled as little as possible. Information concerning the sludge samples used in this study is given in Table 1. (Additional information is available in ref. 1.) Dose rates (field survey) for the samples in the PVC sampling tubes ranged from 1.2 to $2.5 \mathrm{R} / \mathrm{h}$. Radiation fields were considerably higher near small samples dried in the laboratory; dose 


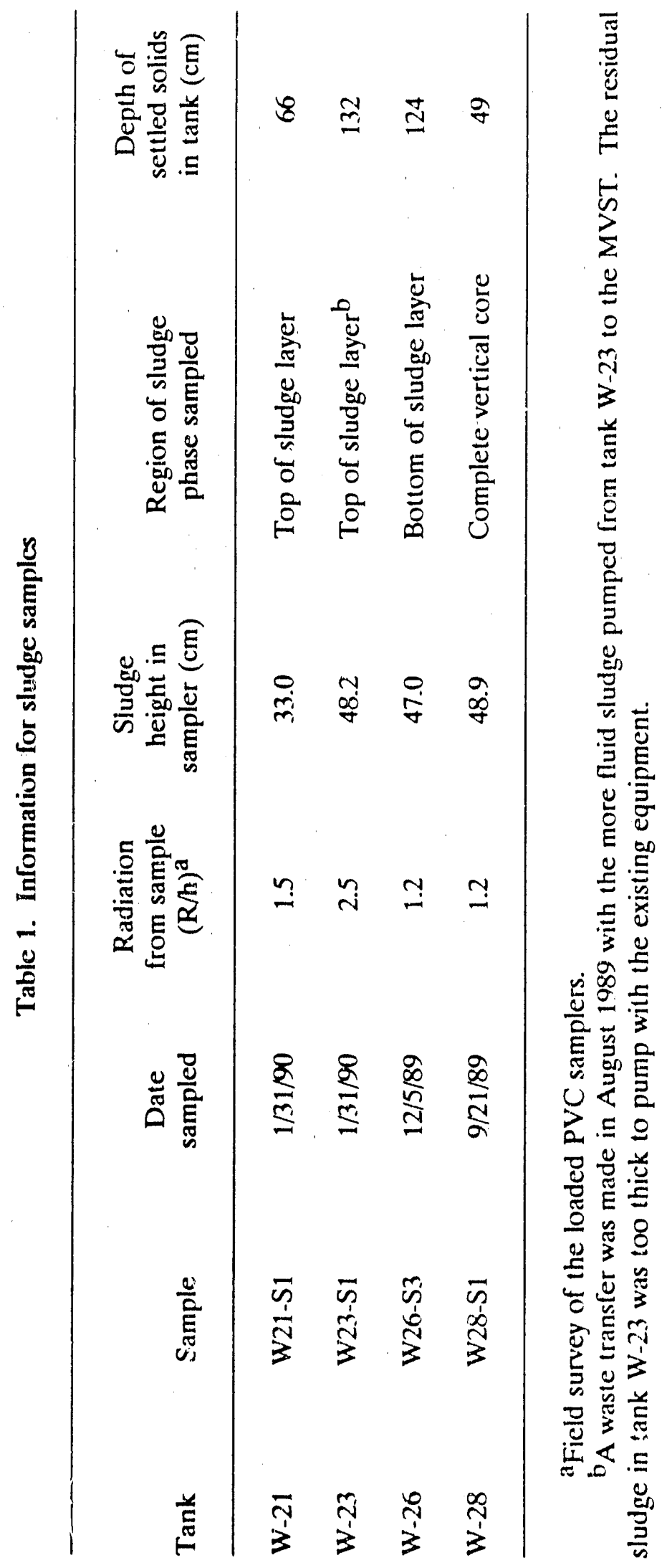


rates of up to $50 \mathrm{R}$ per hour per gram were observed. The increased dose was primarily due to beta particles from ${ }^{90} \mathrm{Sr}$, which had been attenuated in the wet sludges. Sludge samples were handled in a hot cell; small subsamples were removed for analysis in radiochemical hoods and glove boxes. Every effort was made to avoid handling dried samples in order to reduce both exposure and spread of contamination.

Because only sludge directly under the access point can be sampled, the samples may not be representative of other locations in the tank and should be considered as merely an indicator of the tank contents.

\subsection{ANALYSIS PLAN}

Samples described in this report were used for chemical, radiochemical, and physical measurements, so strict sample conservation was imperative. An analysis plan was developed which would yield all the required physical data for a tank using $20 \mathrm{~g}$ of sludge and $60 \mathrm{~mL}$ of supernatant liquid. A flow chart illustrating the physical analysis plan is shown in Fig. 1. The residue from the total solids determination could be dissolved in acid and used in radiochemical assays to conserve sample; however, only the composite sludge samples (i.e., one sample per tank) were assayed (ref. 1) because of budget limitations. 


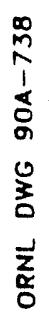

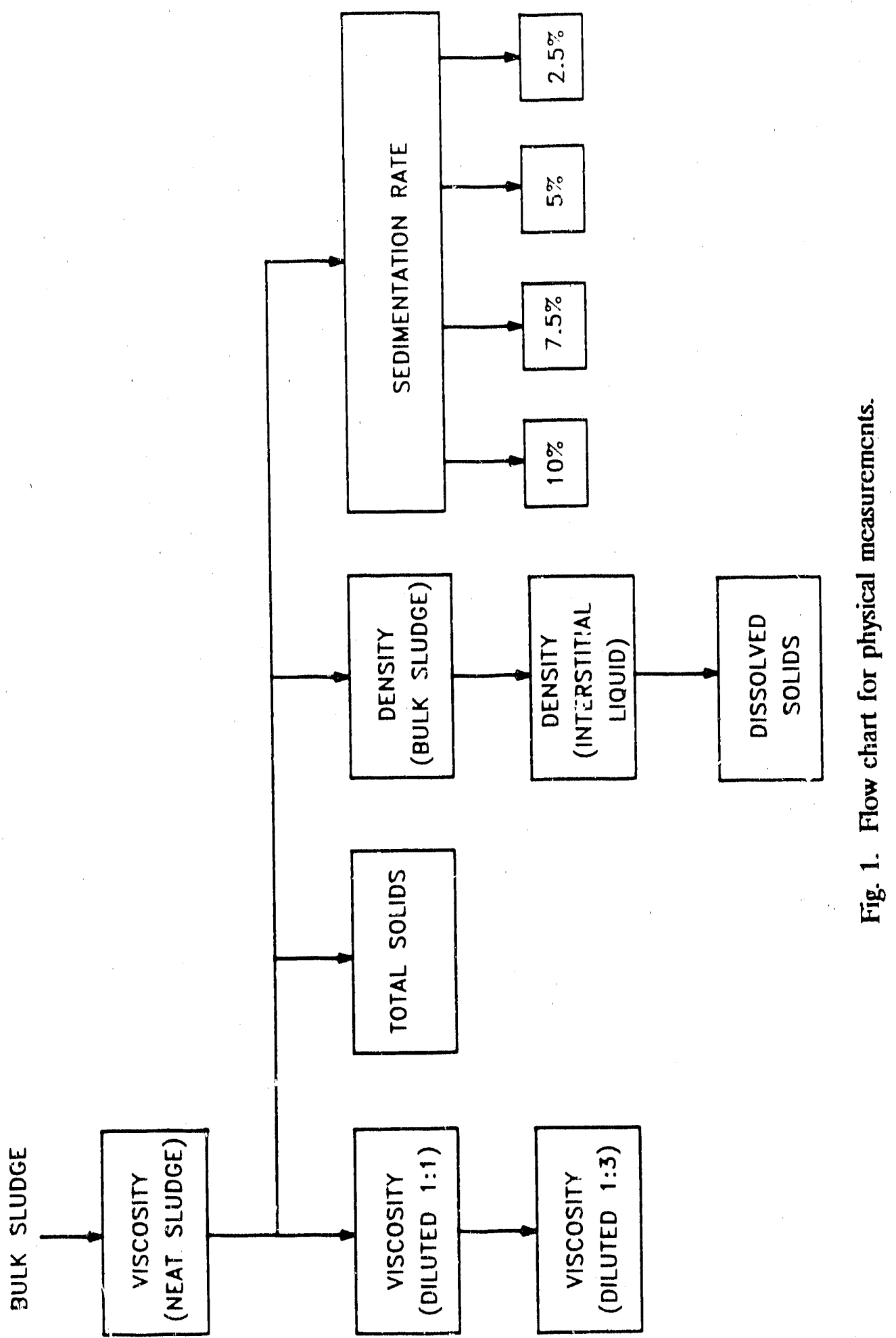




\section{VISCOSITY}

\subsection{METHOD}

Samples of the waste sludges and supernatant (bulk) liquids were assayed for viscosity using a digital Brookfield rotational viscometer ${ }^{3}$ according to ASTM Standard D2196-86, Method $\mathrm{B} .{ }^{4}$ Sludges were tested using the small sample adapter and cylindrical spindles Nos. 18 and 34; liquids were tested using the low-viscosity adapter and cylindrical spindle No. 00 .

Viscosities of liquid samples were measured as received; the sludges were measured as received and/or after dilution with bulk liquid from the same tank. All measurements were made at room temperature $\left(21 \pm 2^{\circ} \mathrm{C}\right)$. Viscosity and shear stress were tracked for each of several shear rates.

\subsection{RESULTS}

Results of the viscosity measurements are summarized in Table 2. Plots of shear stress vs shear rate are shown in Figs. 2-9 for several sludges. The "plastic viscosity" of a sludge, which is the change of shear stress with increasing shear rate, is the slope of the straight-line portion of the plot. The "yield stress" of a sludge, which is the applied stress necessary to initiate flow, is the $y$-intercept of the plot. Both quantities are shown graphically on the plots. The viscosity of a sludge can be reduced considerably if it is mixed with an equal volume of supernatant liquid from the same tank. The stated accuracy of the Brookfield rotational viscometer is $\pm 1 \%$ of the instrument's full-scale reading. Measurements taken with less than $10 \%$ instrument response (i.e., $> \pm 10 \%$ error) are marked as solid black squares on the plots; other data points are $> \pm 1$ and $< \pm 10 \%$. A detailed listing of the viscosity data is presented in Appendix A, Tables A.1-A.4.

Viscosity is a dynamic property which varies with existing conditions. The bulk liquids in these waste tanks were fairly Newtonian (viscosity independent of shear rate), but the sludges exhibited non-Newtonian flow behavior, including pseudoplasticity (viscosity decreases as shear rate increases, see Appendix A, Tables A.1-A.4). Some time-dependent variation $\mathrm{in}_{\mathrm{s}}$ shear stress at constant shear rate was observed, but insufficient data are available to permit positive statements about thixotropic behavior. One sludge (W26-S3) could not be clearly characterized as received. As shown in Fig. 5, the scatter in the shear-stress-vs-shearrate data is too great to permit determination of the plastic viscosity and yield stress. On the 
Table 2. Viscosities of selected waste tank samples

\begin{tabular}{|c|c|c|c|c|}
\hline Property & W21-S1 & W23-S1 & W26-S3 & W28-S1 \\
\hline Bulk liquid $(\mathrm{cP})^{\mathrm{a}}$ & 1.82 & 2.12 & 1.67 & 2.22 \\
\hline \multicolumn{5}{|l|}{ Neat sludge } \\
\hline Plastic viscosity (cP) & 56 & $\mathrm{~b}$ & $\mathrm{c}$ & $7700^{d}$ \\
\hline Yield stress $\left(\right.$ dyn $\left./ \mathrm{cm}^{2}\right)$ & 57 & - & - & 22 \\
\hline \multicolumn{5}{|l|}{ Sludge diluted $1: 1 \mathrm{e}$} \\
\hline Plastic viscosity (cP) & $5.5^{\mathrm{d}}$ & 95 & 70 & 130 \\
\hline Yield stress $\left(\right.$ dyn $\left./ \mathrm{cm}^{2}\right)$ & 2.2 & 44 & 105 & 66 \\
\hline \multicolumn{5}{|l|}{ Sludge diluted $1: 3$} \\
\hline Plastic viscosity (cP) & - & - & - & 55 \\
\hline Yield stress $\left(\right.$ dyn $\left./ \mathrm{cm}^{2}\right)$ & - & - & - & 20 \\
\hline
\end{tabular}

a Bulk liquid samples W21-L3, W23-L1, W26-L2, and W28-L3 were taken from the same tanks as the sludge samples.

${ }^{b}$ Radiation field from undiluted sludge was too intense to permit viscosity measurements using sludge as received.

${ }^{c_{T}}$ There is too much scatter in shear-stress-vs-shear-rate data to determine the plastic viscosity or yield stress (see Fig. 5).

dCoagulated during test; not a true viscosity.

eSludge diluted 1:1 by volume with bulk liquid taken from the same tank as the sludge sample. 


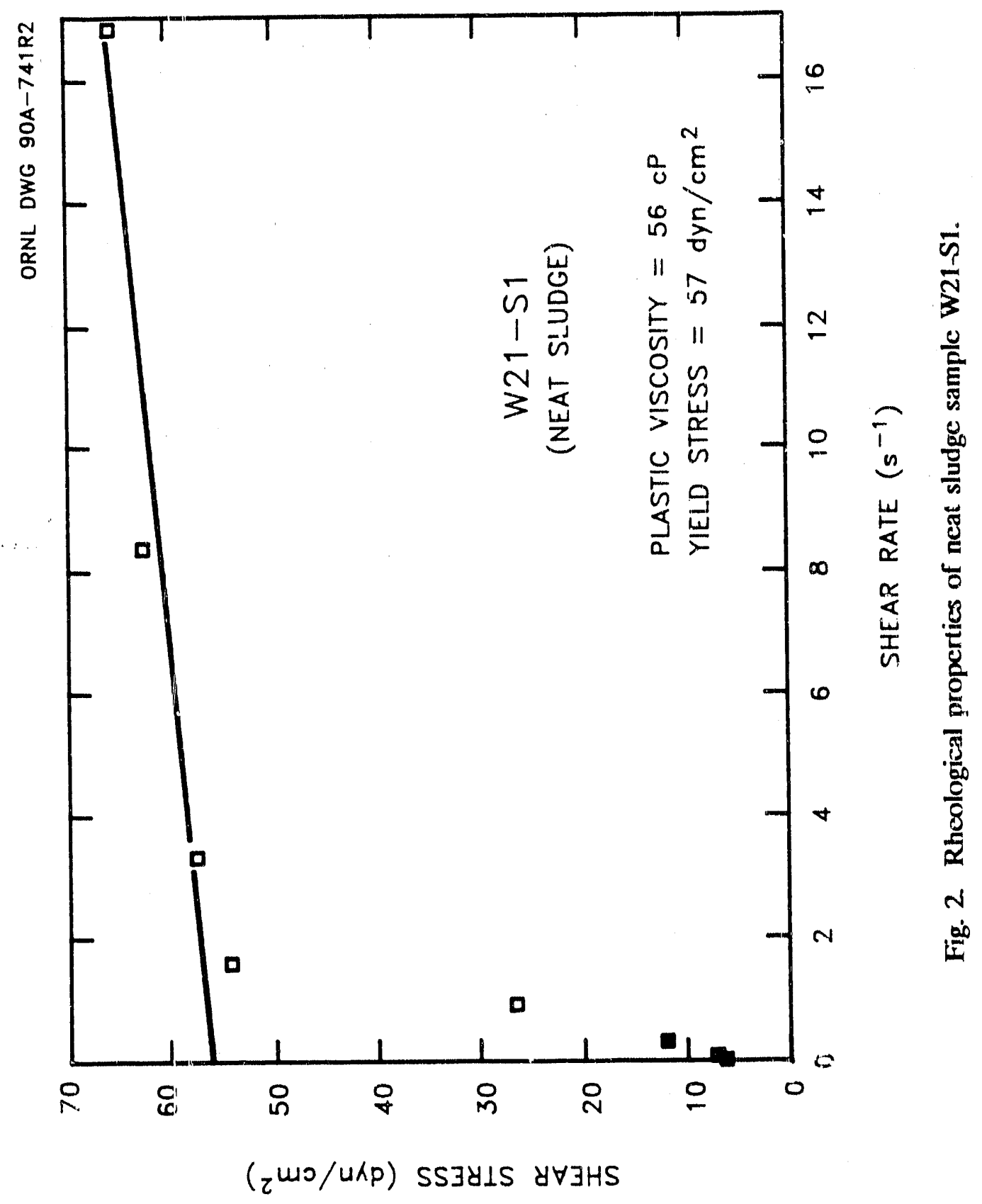




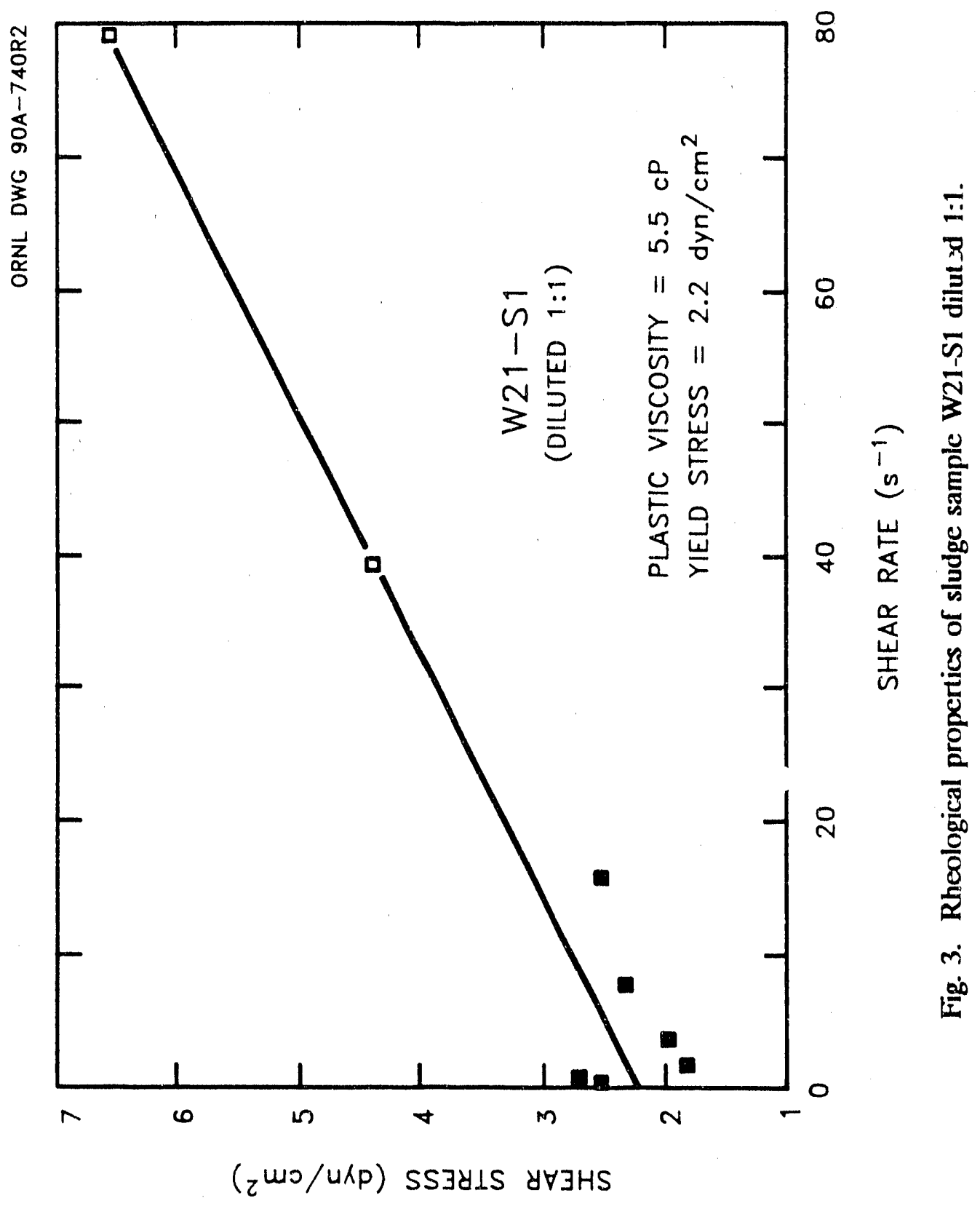




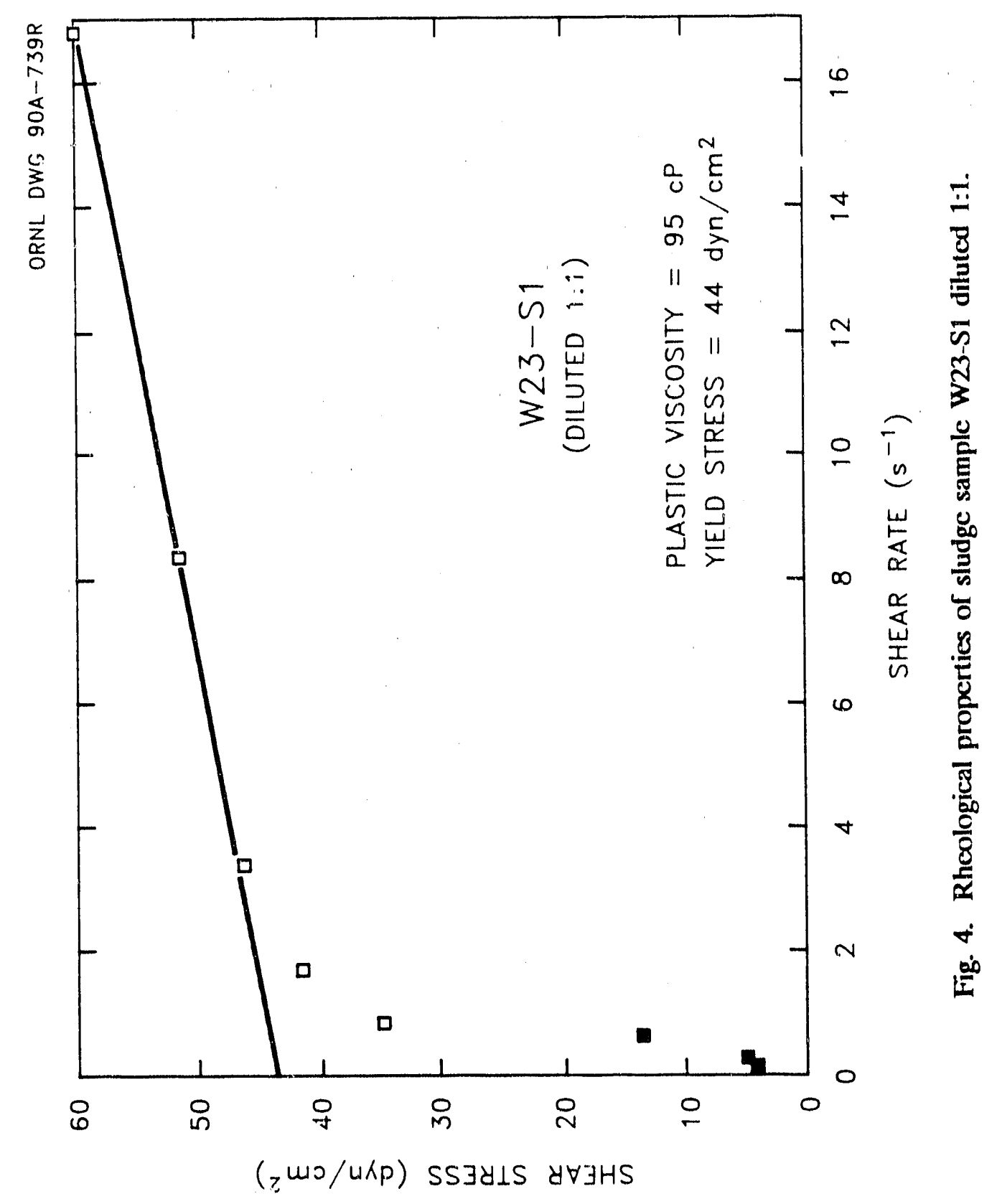




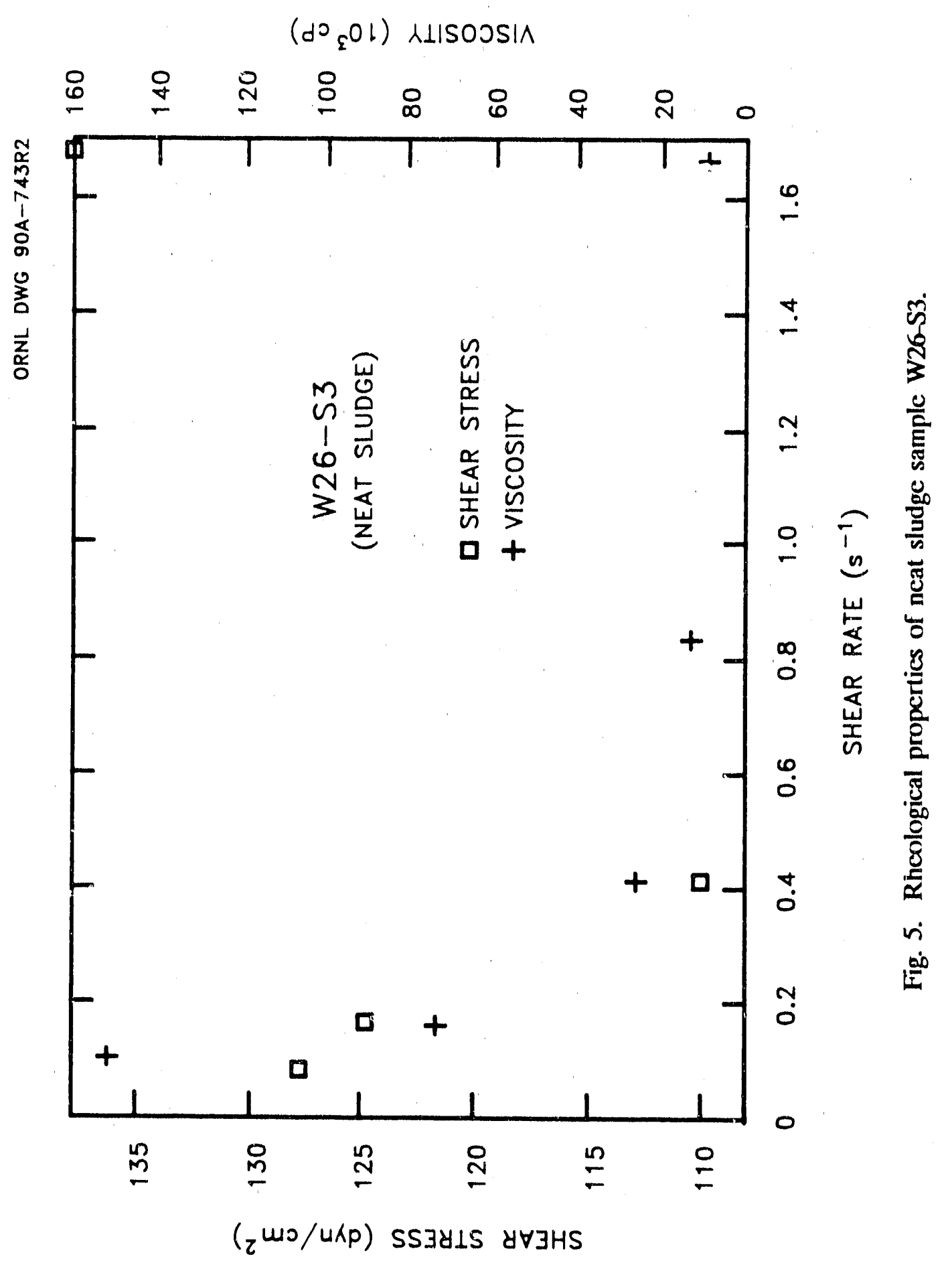




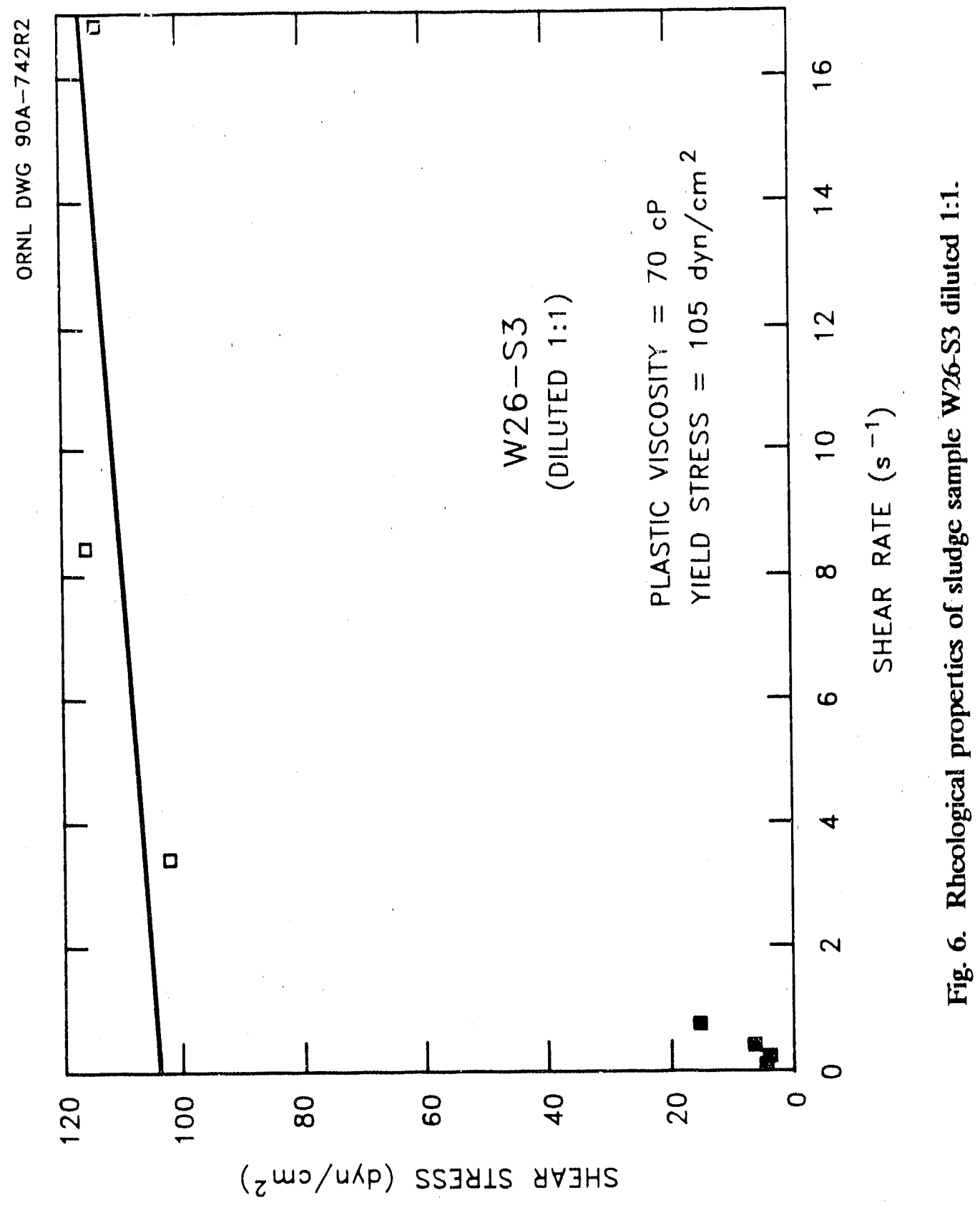




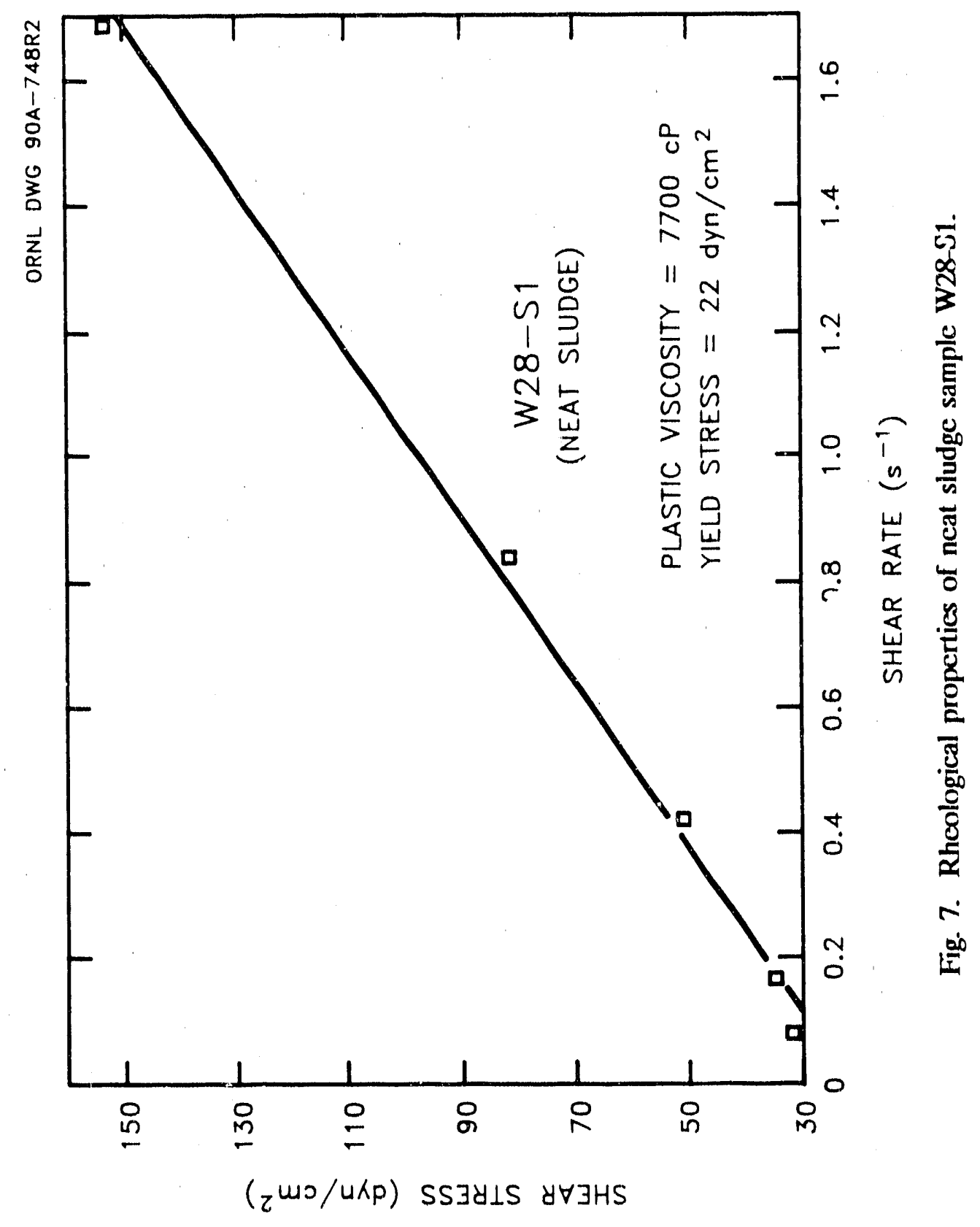




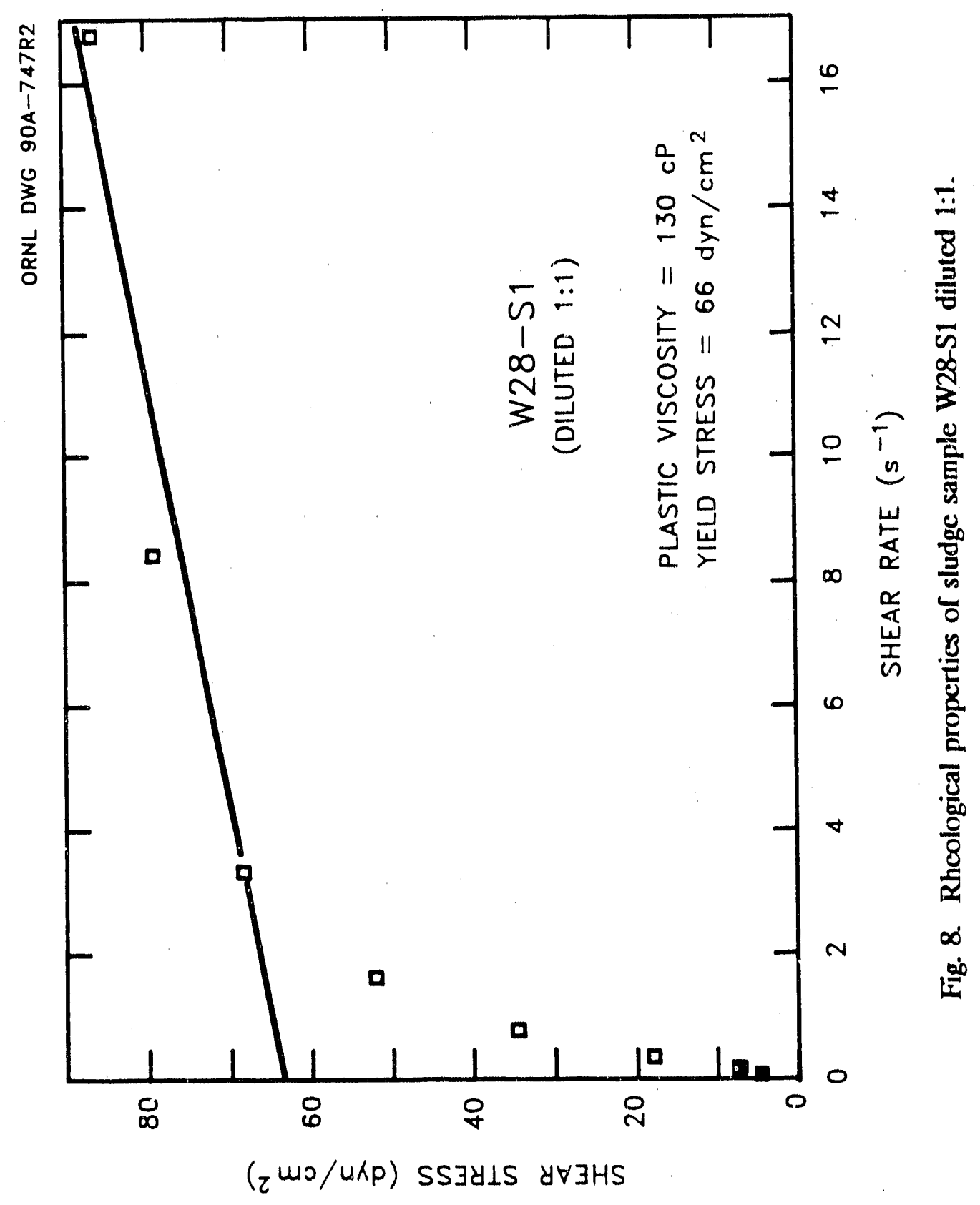




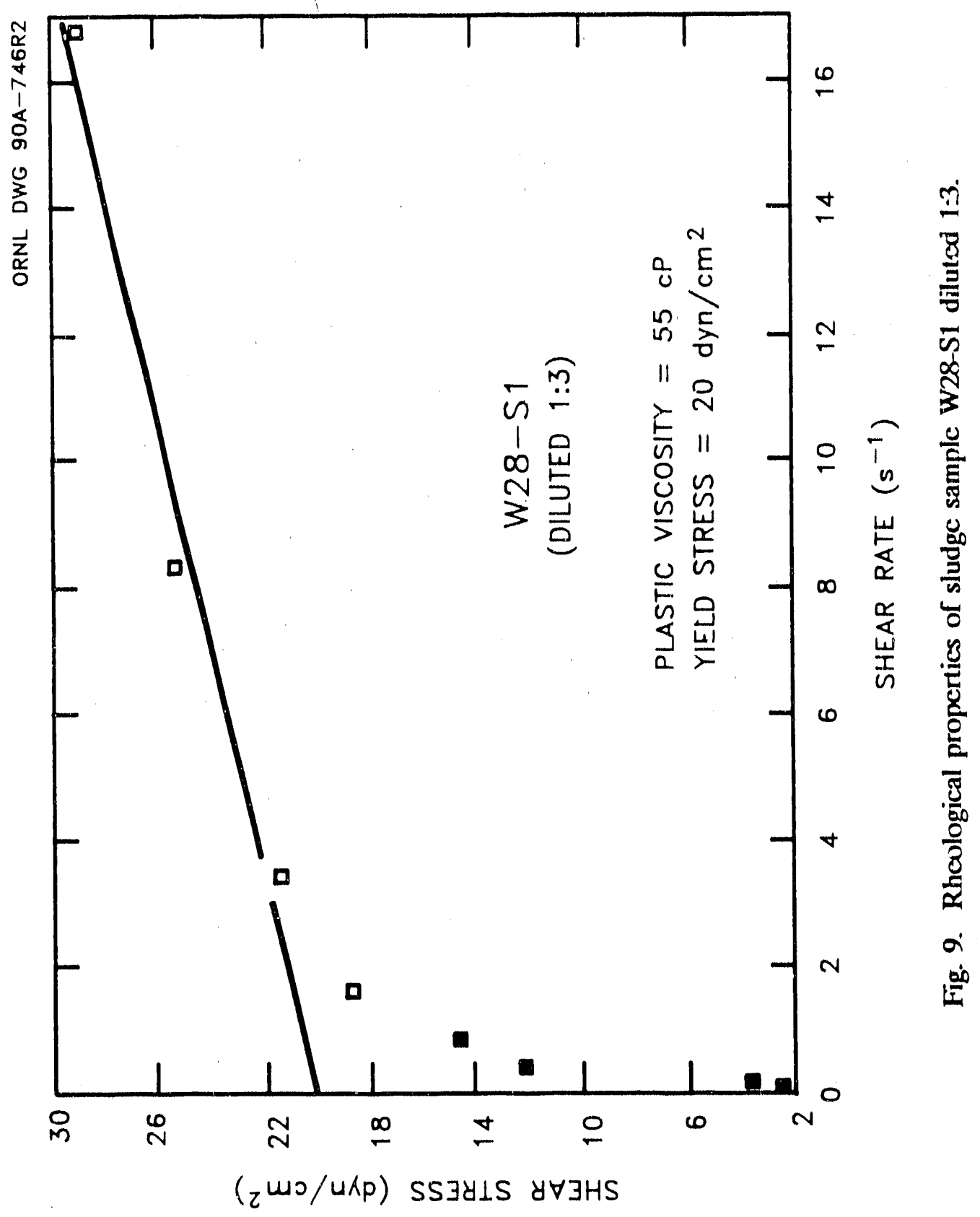




\section{$17 / 18$}

same plot, data are superimposed showing experimentaliy determined apparent viscosity over the same range of shear rates; these data show pseudoplasticity. The same sludge, diluted $1: 1$ with supernatant liquid, showed a more typical curve (Fig. 6).

Both the diluted sample W21-S1 and the neat sample W28-S1 coagulated appreciably during examin: tion. The result was that a liquid layer formed between the sample and the cup, while the sludge rotated with the spindle almosi without internal slippage. Therefore, data from these measurements cannot be considered true viscosities. Large granules in a sludge would frequently jam between the viscometer sample cup and spindle No. 18. Whenever possible, the smaller spindle No. 34 was used; however, the radiation field from sample W23-S1 was too intense to use such a large $(12-\mathrm{mL})$ sample. These problems are amplified using small samples. More meaningful data would be obtained from troublesome samples using larger $(500-\mathrm{mL})$ samples and special apparatus such as a T-bar spindle with a helical path. However, the high radiation level limits the sample quantity that can be collect ed in the field or handled in a radiochemical hood or glove box. 


\section{DENSITY AND SOLIDS MEASUREMENTS}

\subsection{METHOD}

In principle, density and solids content are simple measurements to make; in this study, however, accurate values, particularly the percentages of dissolved and undissolved solids were difficult to obtain. The liquids in these tanks have high sait contents (abou: $4 \underline{\mathrm{M}}$ in nitrate), and most have high $\mathrm{pH}$ levels. If a sludge were simply vacuum filtered, the filter cake would retain some of the interstitial liquid. After being dried, the solids would contain an indeterminate mass of salts that had been dissolved in the original sample. If the filter cake were rinsed with water to remove the salts, some of the material that was insoluble in the original matrix might dissolve. The following method provides an indirect means of measuring the density and the solids content of the whole sludge, as well as of its disso!ved and undissolved components.

Seven measurements were performed on each sludge sample to determine the density and the solids content of the whole sludge, its component interstitial liquid, and the component undissolved solids. Two portions of a sludge sample were required for these measurements. During these measurements, each sludge was inspected and visuai and tactile impressions (i.e., color, texture) were recorded (see ref. 1).

The first portion of sludge, about $5 \mathrm{~g}$, was packed into a short length of Teflon tubing. After the outside of the packed tubing had been wiped clean, the sample was lowered into a tared, graduated $15-\mathrm{mL}$ glass centrifuge tube. The sludge was carefully extruded into the centrifuge tube using a glass rod as a piston so that no sludge was smeared on the inner wall of the centrifuge tube above the bulk of the sample. The centrifuge tube was then sealed with its screw cap and spun at a high rate $(>4000 \mathrm{G})$ for 15 min to compact the solids and to displace any entrained air from the sludge. After centrifugation, a layer of clear liquid was visible above the compacted solids; the total volume of the sample was taken as the sum of the liquid and compacted solids volumes. The centrifuge tube was reweighed to determine the bulk sludge mass. The density of the bulk sludge was calculated by dividing the mass of the bulk sludge by the sample volume.

The separated interstitial liquid (see above) was withdrawn from the centrifuge tube and filtered through a $0.45-\mu \mathrm{m}$ syringe filter. Then, $1.00 \mathrm{~mL}$ of the filtered liquid was pipetted into a tared $10-\mathrm{mL}$ glass beaker. This beaker was weighed to determine the 
liquid mass and subsequently dried for $16 \pm 1 \mathrm{~h}$ at $110 \pm 5^{\circ} \mathrm{C}$ before reweighing to determine the mass of the residual dried salts. These measurements give the density $(\mathrm{g} / \mathrm{mL})$ of the interstitial liquid, the quantity of dissolved solids per milliliter of liquid, and the water loss per milliliter of liquid upon drying.

The second portion of sludge was used to determine the percentage of total solids in the bulk sludge. About $1 \mathrm{~g}$ of the sludge was placed into a tared $10-\mathrm{mL}$ beaker. The beaker containing the sample was reweighed to determine the wet sludge mass and then dried for $16 \pm 1 \mathrm{~h}$ at $110 \pm 5^{\circ} \mathrm{C}$. The beaker containing the dried solids was weighel.

\subsection{RESULTS}

Results of the density and solids measurements are summarized in Table 3. Details of the calculations are given in Appendix B. The density of the bulk sludge ranged from 1.34 to $1.44 \mathrm{~g} / \mathrm{mL}$, while that of the undissolved solids ranged from 1.68 to $2.44 \mathrm{~g} / \mathrm{mL}$. The densities of both the interstitial liquid and the bulk tank liquid (which was used in the sedimentation experiments described in Sect. 5) are shown in Table 3. The dissolved solids comprise 24 to 29 wt \% of the bulk sludge and the undissolved solids 22 to $25 \mathrm{wt} \%$.

The sludges were added to the tanks in layers at various times. Wastes have been transferred from one tank to another within the system, and some liquid wastes have been removed from the system for solidification. The interstitial liquid associated with a sludge does not necessarily have the same composition as the bulk liquid in the same tank. For example, the sodium/potassium ratio in the sludge is sometimes different from that in the bulk liquid; and in tank W-21, the pH of the bulk liquid was 0.8 while the $\mathrm{pH}$ of the sludge liquid was 7.* All of the other tank liquids are basic. Volume readings were accurate to $\pm 0.1 \mathrm{~mL}$, and mass readings were taken to the nearest $0.0001 \mathrm{~g}$. Uncertainties for density and solids measurements are estimated at $\pm 5 \%$. No attempt was made to account for waters of hydration or crystallization in these measurements.

*Tank W-21 receives liquid waste from the process waste treatment plant. Historically, it has served as a feed tank and as a concentrate storage tank for the low-level waste (LLW) evaporator and may contain these sludges. The other tanks, which are all basic, contain predominantly LLW concentrates. 


$$
21 / 22
$$

Table 3. Density and solids measureme ts

\begin{tabular}{lllll}
\hline \multicolumn{1}{c}{ Property } & W21-S1 & W23-S1 & W26-S3 & W28-S1 \\
\hline Density & & & & \\
$\quad$ Bulk liquid (g/mL) & & & & \\
Bulk sludge (g/mL) & 1.2391 & 1.2423 & 1.2177 & 1.2852 \\
Interstitial liquid (g/mL) & 1.34 & 1.44 & 1.36 & 1.40 \\
Undissolved solids (g/mL) & 1.26 & 1.27 & 1.23 & 1.29 \\
& & 2.44 & 2.16 & 2.00 \\
Sludge solids & & & & \\
Total solids (wt \%) & 51.9 & 52.4 & 46.0 & 51.4 \\
Dissolved solids (wt \%) & 28.2 & 27.5 & 23.6 & 29.4 \\
Undissolved solids (wt \%) & 23.7 & 24.9 & 22.4 & 22.0 \\
\hline
\end{tabular}

${ }^{a}$ Bulk liquid samples W21-L3, W23-L1, W26-L2, and W28-L3 were taken from the same tanks as the sludge samples. 


\section{SEDIMENTATION RATE}

\subsection{METHIOD}

The sedimentation ratc of each sludge was determined by placing small portions $(0.2$ to $2 \mathrm{~mL}$ of the bulk sludge) into four $10-\mathrm{mL}$ graduated mixing cylinders containing bulk liquid from the same tank so that the combined volume was $10.0 \mathrm{~mL}$ in each cylinder. The mixing cylinders were stoppered and their contents mixed gently by repeated inversion for $1 \mathrm{~min}$. After mixing, the cylinders were righted and tapped sharply several times to release entrained air. As the solids settled, the positions of the liquid-slurry interface were recorded at 1-min intervals for a total of $30 \mathrm{~min}$. When sedimentation tests were complete, the slurries were remixed, decanted into graduated centrifuge tubes, and centrifuged at a high rate $(>4000 \mathrm{G})$ for $15 \mathrm{~min}$, and the volume of compacted solids was measured. This provided a uniform basis for comparing undissolved solids contents.

\subsection{RESULTS}

Factors that influence the settling rates of individual particles include solids concentration, liquid density and viscosity, particle density, and particle radius. When a slurry is allowed to settle, the particles are initially separate and have zero average downward velocity. As the particles agglomerate and are accelerated by gravity, they settle faster until the force of gravity is balanced by the viscous drag exerted by the liquid they are falling through. The particles continue at constant velocity until they begin to pile up on the container bottom. A typical waste tank sludge sedimentation rate curve is given in Fig. 10.

Sedimentation data were recorded for several slurries of each sample, ranging from very dilute to partially compacted. (If a slurry was too dilute, coagulation was inefficient and the lighter particles settled poorly. If the siurry was too concentrated, the sludge was already partially compacted and the particles could not fall freely through the liquid.) Results were plotted for each dilution as settling rate vs elapsed time. Terminal velocities were plotted as their logarithms vs volume of compacted solids. The latter plots were extrapolated to infinite dilution to determine true sedimentation rates. Figure 11 shows a plot of the concentration dependence of the sedimentation rate for a typical waste tank sludge. 


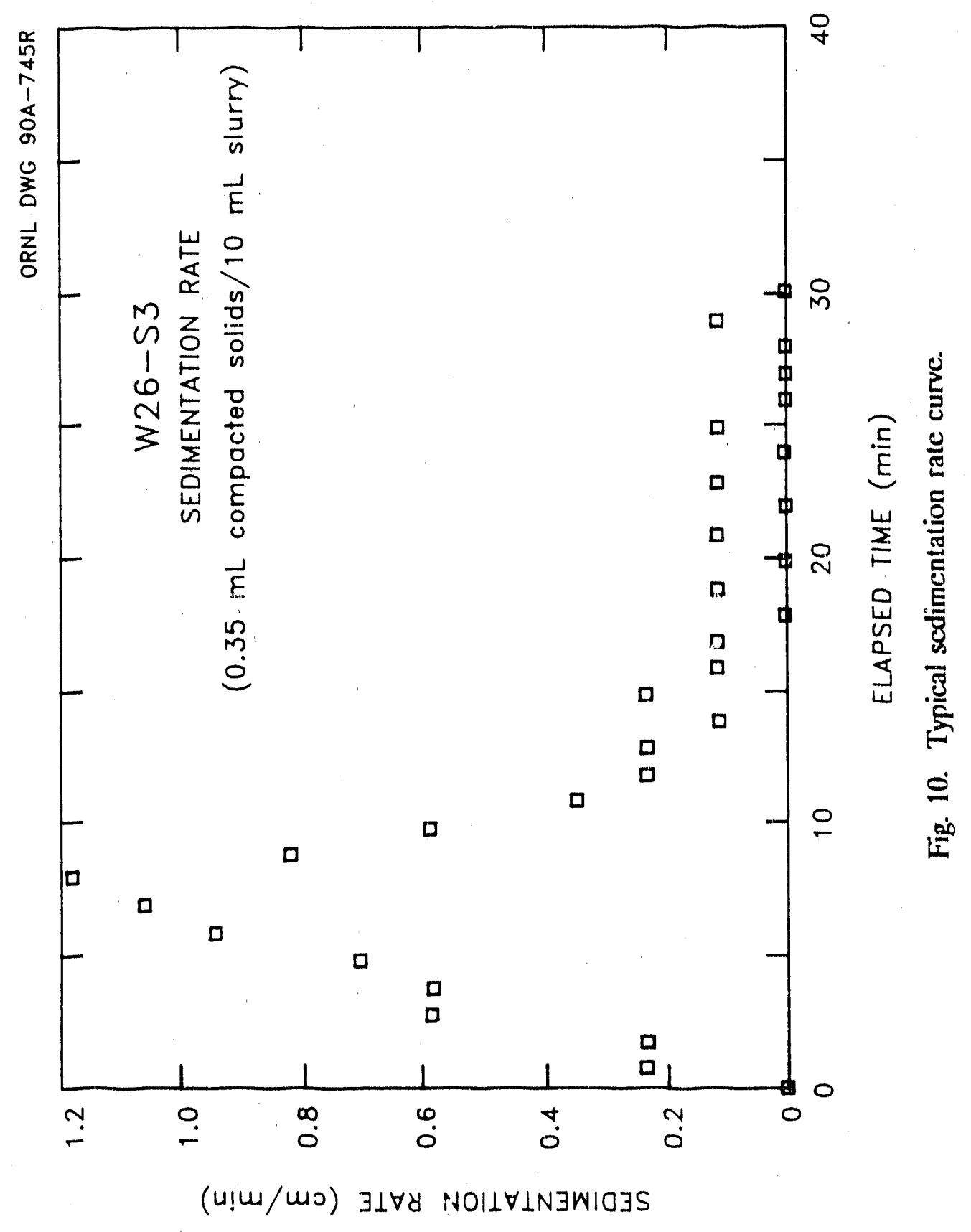




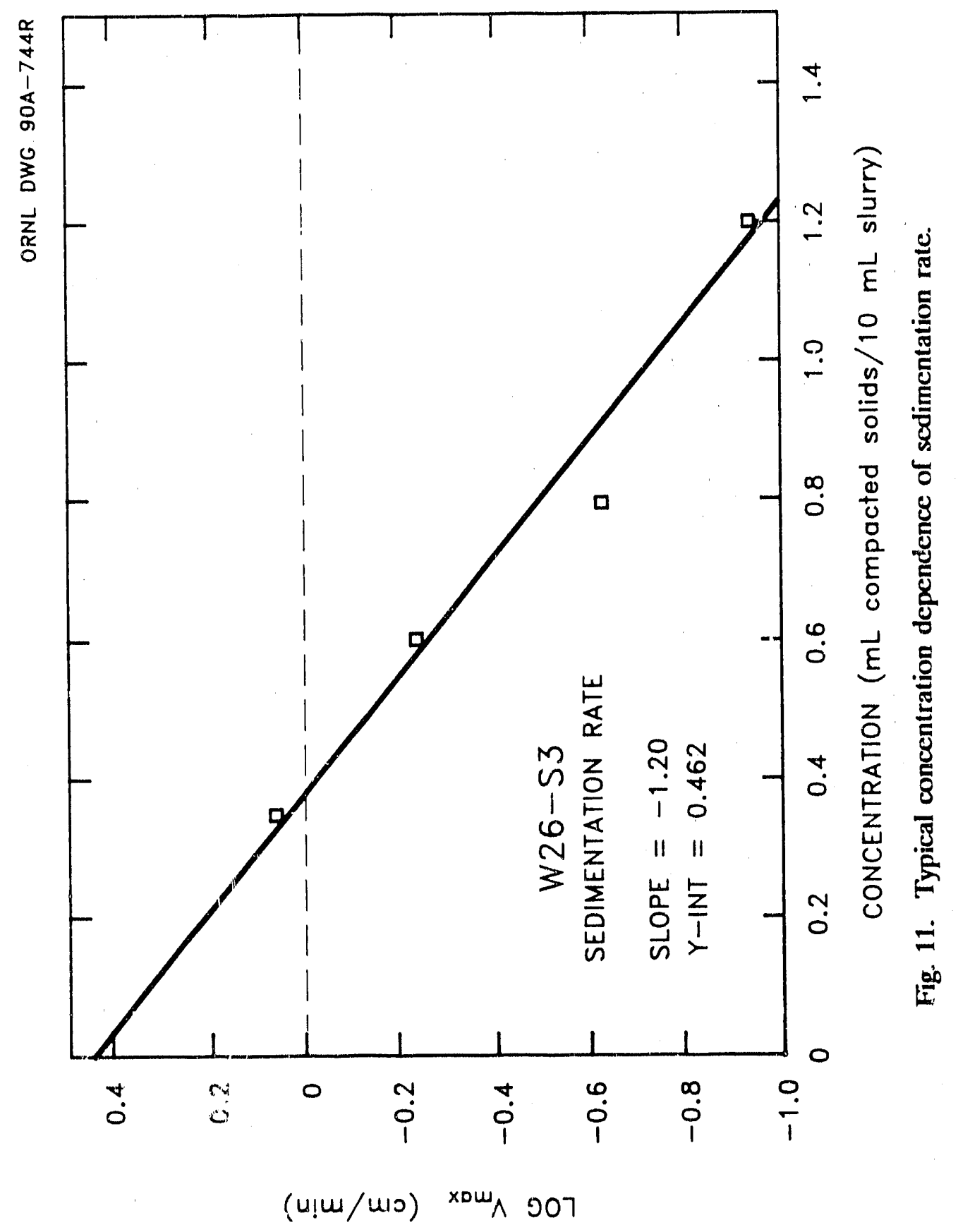


The sedimentation rates (at terminal velocity) for the sludge samples from three of the tanks are about 3 to $4 \mathrm{~cm} / \mathrm{min}$ (Table 4). The rate for the sample W21-S1 is lower, about $1 \mathrm{~cm} / \mathrm{min}$.

Typical waste tank sludges have both granular and flocculent components; the flocculent component appears to make up about $90 \%$ of the sludge mass. The granules settle faster, as a rule, but are obscured from view by the floc. The sedimentation rates reported here are rates for the flocculent particles only. Data from these measuremenis are listed in Appendix A, Exhibits A.1-A.4.

Table 4. Floc sedimentation rate ${ }^{a}$

\begin{tabular}{cc}
\hline Sample & Terminal velocity $(\mathrm{cm} / \mathrm{min})$ \\
\hline W21-S1 & 1.0 \\
W23-S1 & 3.9 \\
W26-S3 & 2.9 \\
W28-S1 & 2.9 \\
\hline
\end{tabular}

asedimentation rate in bulk liquid samples W21-L3, W23-L.1, W26-L2, and W28-L3, which were taken from the same tanks as the sludge samples. 


\section{PARTICLE SIZE}

During the sedimentation tests described in Sect. 5, sludge particles dispersed through the liquid during the initial agitation, then were seen to agglomerate when mechanical shearing stopped. An estimate of agglomerate size may be made by applying Stokes' law, 5 which describes spherical particles falling through a viscous fluid under the influence of gravity. It relates the terminal velocity of such a particle to the particle size, particle and liquid densities, and the liquid viscosity, as follows:

$$
u=\frac{2 g r^{2}\left(p-p^{\prime}\right)}{9 \eta},
$$

where $u=$ terminal velocity at zero concentration,

$g=$ arceleration due to gravity,

$r=$ radius of the falling particle,

$\rho=$ particle density,

$\rho^{\prime}=$ liquid density,

$\eta=$ liquid viscosity.

Agglomerate size was computed for each of the sludges using experimental values for liquid density and viscosity, particle density, and terminal velocity (Table 5). Application of Stokes' law yields only approximate particle sizes because of several factors: (1) sludge particle agglomerates are not spherical, (2) falling particles may be porous and carry some of the bulk liquid with them as they fall, and (3) terminal velocity was only measured for the slowest-settling fraction.

Table 5. Particle size estimates

\begin{tabular}{lc}
\hline Sample & $\begin{array}{c}\text { Agglomerate radius } \\
(\mu \mathrm{m})\end{array}$ \\
\hline W21-S1 & 18 \\
W23-S1 & 23 \\
W26-S3 & 20 \\
W28-S1 & 26 \\
\hline
\end{tabular}




\section{DISCUSSION}

The design parameters for the WHPP will be influenced by the physical characteristics of the feedstock. Pump configuration and size depend on the rheological properties of the sludges to be pumped. An estimate of the rheology of the diluted sludge will be useful, since it may be necessary to dilute the sludge to mobilize it from the tank or to reduce the horsepower requirements for pump drivers. Knowledge of sedimentation behavior will help in choosing mass transport conditions. The viscosity of a sludge can be reduced considerably if it is mixed with an equal volume of supernatant liquid from the same tank. At this dilution, the solids are still partially compacted; such a mixture would be fairly stable during pumping and transport.

Table 6 summarizes some physical properties of selected waste tank sludges. Values for viscosity, sedimentation rate, and particle size listed here assume that the interstitial liquid associated with a sludge and the bulk liquid from the same tank have the same chemical composition; that is, no chemical or physical change occurred when the undissolved solids in a sludge were suspended in the bulk liquid from the same tank. This assumption is not always warranted; for example, in one tank, the $\mathrm{pH}$ of the bulk liquid was 0.8 and the $\mathrm{pH}$ of the sludge liquid was 7. Such chemical dissimilarity could have a profound impact on the physical properties of a sludge, particularly when the contents of a tank are mixed.

For the WHPP design, it has been proposed that solids be transported from the waste tank to the plant by using water as a transport fluid. (If some suspended solids dissolved in the transpoit medium, it might affect the physical properties.) Advantages of this strategy could include reduced exposure from beta and gamma radiation during sludge handling and separation of shorter-lived soluble radionuclides, such as ${ }^{137} \mathrm{Cs}$ and ${ }^{90} \mathrm{Sr}$, from transuranic waste. A new set of experiments is being planned to assess the solubilities of sludge components in water under process conditions. 
Table 6. Physical properties of selected waste tank samples

\begin{tabular}{|c|c|c|c|c|}
\hline Physical property & W21-S1 & W23-S1 & W26-S3 & $\mathrm{W} 28-\mathrm{S} 1$ \\
\hline \multicolumn{5}{|l|}{ Density } \\
\hline Bulk liquid $(\mathrm{g} / \mathrm{mL})^{\mathrm{a}}$ & 1.2391 & 1.2423 & 1.2177 & 1.2852 \\
\hline Bulk sludge $(\mathrm{g} / \mathrm{mL})$ & 1.34 & 1.44 & 1.36 & 1.40 \\
\hline Interstitial liquid $(\mathrm{g} / \mathrm{mL})$ & 1.26 & 1.27 & 1.23 & 1.29 \\
\hline Undissolved solids $(\mathrm{g} / \mathrm{mL})$ & 1.68 & 2.44 & 2.16 & $2 .(x)$ \\
\hline \multicolumn{5}{|l|}{ Sludge solids } \\
\hline Total solids (wt \%) & 51.9 & 52.4 & 46.0 & 51.4 \\
\hline Dissolved solids (wt \%) & 28.2 & 27.5 & 23.6 & 29.4 \\
\hline Undissolved solids (wt \%) & 23.7 & 24.9 & 22.4 & 22.0 \\
\hline \multicolumn{5}{|l|}{ Viscosity } \\
\hline Bulk liquid (cP) ${ }^{a}$ & 1.82 & 2.12 & 1.67 & 2.22 \\
\hline \multicolumn{5}{|l|}{ Neat sludge } \\
\hline Plastic viscosity (cP) & 56 & b & c & $77000^{d}$ \\
\hline $\begin{array}{l}\text { Yield stress }\left(\text { dyn } / \mathrm{cm}^{2}\right) \\
\text { Sludge diluted } 1: 1 \mathrm{e}^{\mathrm{e}}\end{array}$ & 57 & & & 22 \\
\hline Plastic viscosity $(\mathrm{cP})$ & $5.5^{\mathrm{d}}$ & 95 & 70 & 130 \\
\hline Yicld stress $\left(\mathrm{dyn} / \mathrm{cm}^{2}\right)$ & 2.2 & 44 & 105 & 66 \\
\hline \multicolumn{5}{|l|}{ Sludge diluted $1: 3$} \\
\hline Plastic viscosity $(\mathrm{cP})$ & - & - & . & 55 \\
\hline Yield stress $\left(\right.$ dyn $\left./ \mathrm{cm}^{2}\right)$ & - & - & - & 20 \\
\hline Agglomerate radius $(\mu \mathrm{m})$ & 18 & 23 & 20 & 26 \\
\hline \multicolumn{5}{|l|}{ Floc Sedimentation Rate } \\
\hline Terminal velocity $(\mathrm{cm} / \mathrm{min})$ & 1.0 & 3.9 & 2.9 & 2.9 \\
\hline
\end{tabular}

${ }^{a}$ Buik liquid samples W21-L3, W23-L1, W26-L2, and W28-L3 were taken from the same tanks as the sludge samples.

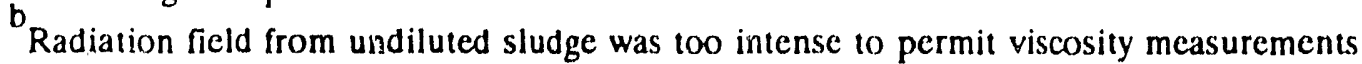
using sludge as received.

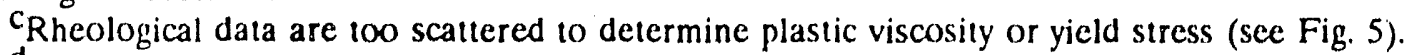

dCoagulated during test; not a true viscosity.

Sludge diluted 1:1 by volume with bulk liquid taken from the same tank as the sludge sample. 


\section{ACKNOWLEDGMENTS}

The authors wish to express their appreciation to E. Z. Youngblood and H. O. Weeren for their helpful comments in reviewing this report. 


\section{REFERENCES}

1. M. B. Sears et al., Sampling and Analysis of Radioactive Liquid Wastes and Sludges in the Melton Valley and Evaporator Facility Storage Tanks ai ORNL, ORNL/TM-11652, September 1990.

2. F. J. Peretz, B. R. Clark, C. B. Scott, and J. B. Berry, Characterization of Low-Level Liquid Wastes at the Oak Ridge National Laboratory, ORNL;TM-10218, December 1986.

3. Brookfield Engineering Laboratories, Inc., More Solutions to Sticky Problems, 1987.

4. ASTM Standard D2196-86, "Rheological Properties of Non-Newtonian Materials by Rotational (Brooiffield) Viscometer," 1986.

5. S. Glasstone, Textbook of Physical Chemistry, D. Van Nostrand Co., New York, pp. 497-498, 1946 . 
APPENDIX A

LISTING OF PHYSICAL PROPERTIES DATA 


\section{APPENDIX A}

\section{LISTING OF PHYSICAL PROPERTIES DATA}

The tables in this appendix list the raw numeric data obtained from the physical

measurements described in this report. They also include observations made during the measurements. 
Table A.1. Viscositics of bulk liquid and sludge, tank W-21a

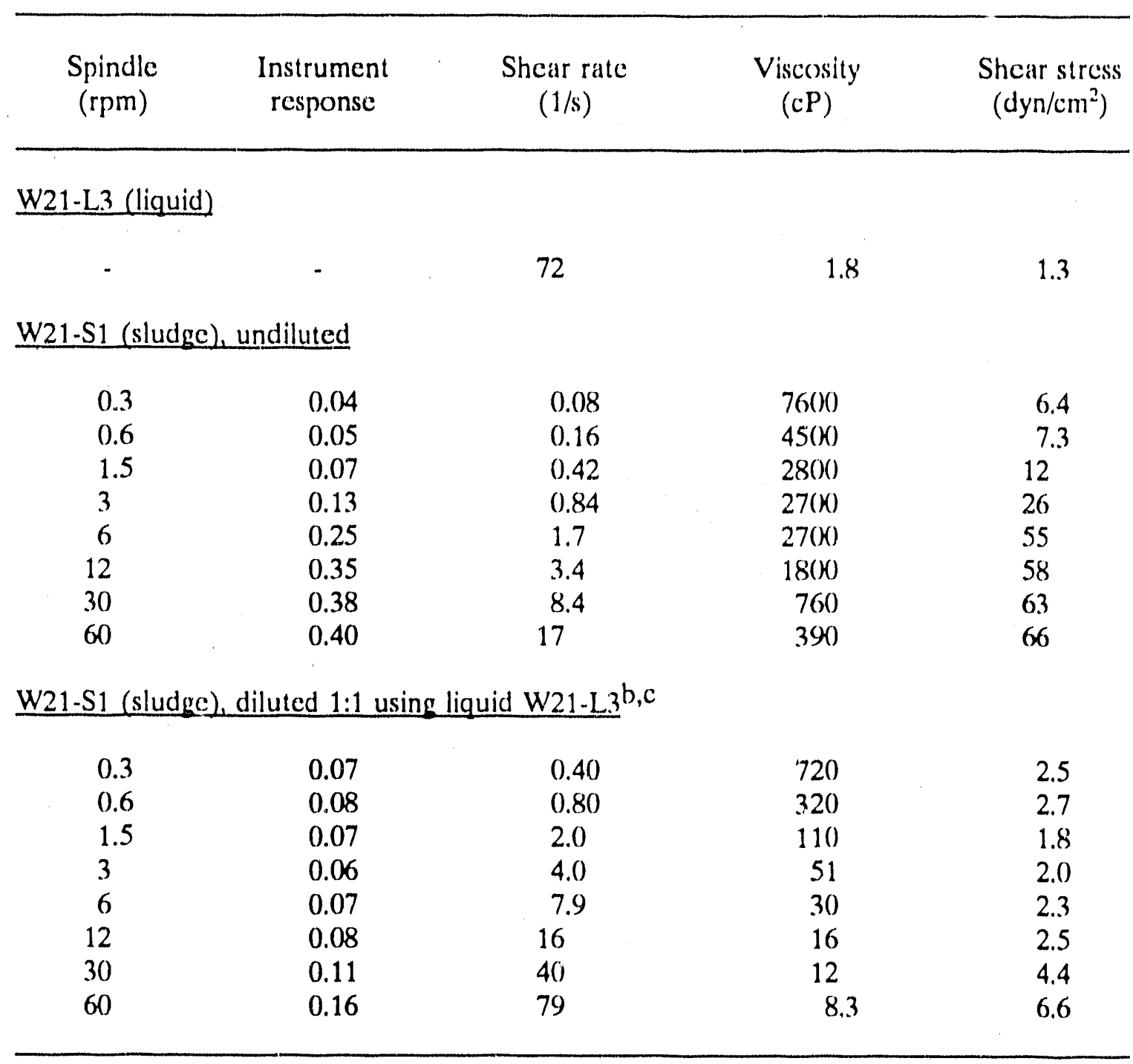

a Measured by Brookfield rotational viscometer.

b The diluted sample appeared to coagulate so that solids adhered to and rotated with the spindle. Most slippage occurred within a thin liquid layer which formed between the solids mass and sample cup. Therefore, the affected measurements do not assay true viscosity.

${ }^{\mathrm{c}}$ Measured using spindle No. 18. 
Table A.2. Viscositics of bulk liquid and sludge, tank W-23a,b

\begin{tabular}{|c|c|c|c|c|}
\hline $\begin{array}{l}\text { Spindle } \\
\text { (rpm) }\end{array}$ & $\begin{array}{l}\text { Instrument } \\
\text { response }\end{array}$ & $\begin{array}{c}\text { Shear rate } \\
(1 / \mathrm{s})\end{array}$ & $\begin{array}{l}\text { Viscosity } \\
\text { (cP) }\end{array}$ & $\begin{array}{l}\text { Thear stress } \\
\left(\text { dyn } / \mathrm{cm}^{2}\right)\end{array}$ \\
\hline \multicolumn{5}{|c|}{ W23.L1 (liquid) } \\
\hline - & - & 76 & 2.1 & 1.6 \\
\hline \multicolumn{5}{|c|}{ W23-S1 (sludge), diluted 1:1 using liquid W23-L1 } \\
\hline 0.3 & 0.02 & 0.08 & 4600 & 3.9 \\
\hline 0.6 & 0.03 & 0.17 & 2700 & 4.5 \\
\hline 1.5 & 0.08 & 0.42 & 3200 & 13 \\
\hline 3 & 0.21 & 0.84 & 4200 & 35 \\
\hline 6 & 0.25 & 1.7 & 2500 & 42 \\
\hline 12 & 0.27 & 3.4 & 1400 & 47 \\
\hline 30 & 0.31 & 8.4 & 630 & 53 \\
\hline 60 & 0.36 & 16.8 & 360 & 60 \\
\hline
\end{tabular}

aUndiluted sludge was too viscous to measure using the large spindle (No. 18). The radiation field near the undiluted sludge was too intense $(700 \mathrm{mR} / 20 \mathrm{~g})$ to allow the use of the smaller spindle (No. 34) and a larger sample volume.

b Measured by Brookfield rotational viscometer. 
Table A.3. Viscositics of bulk liquid and sludge, tank W-26

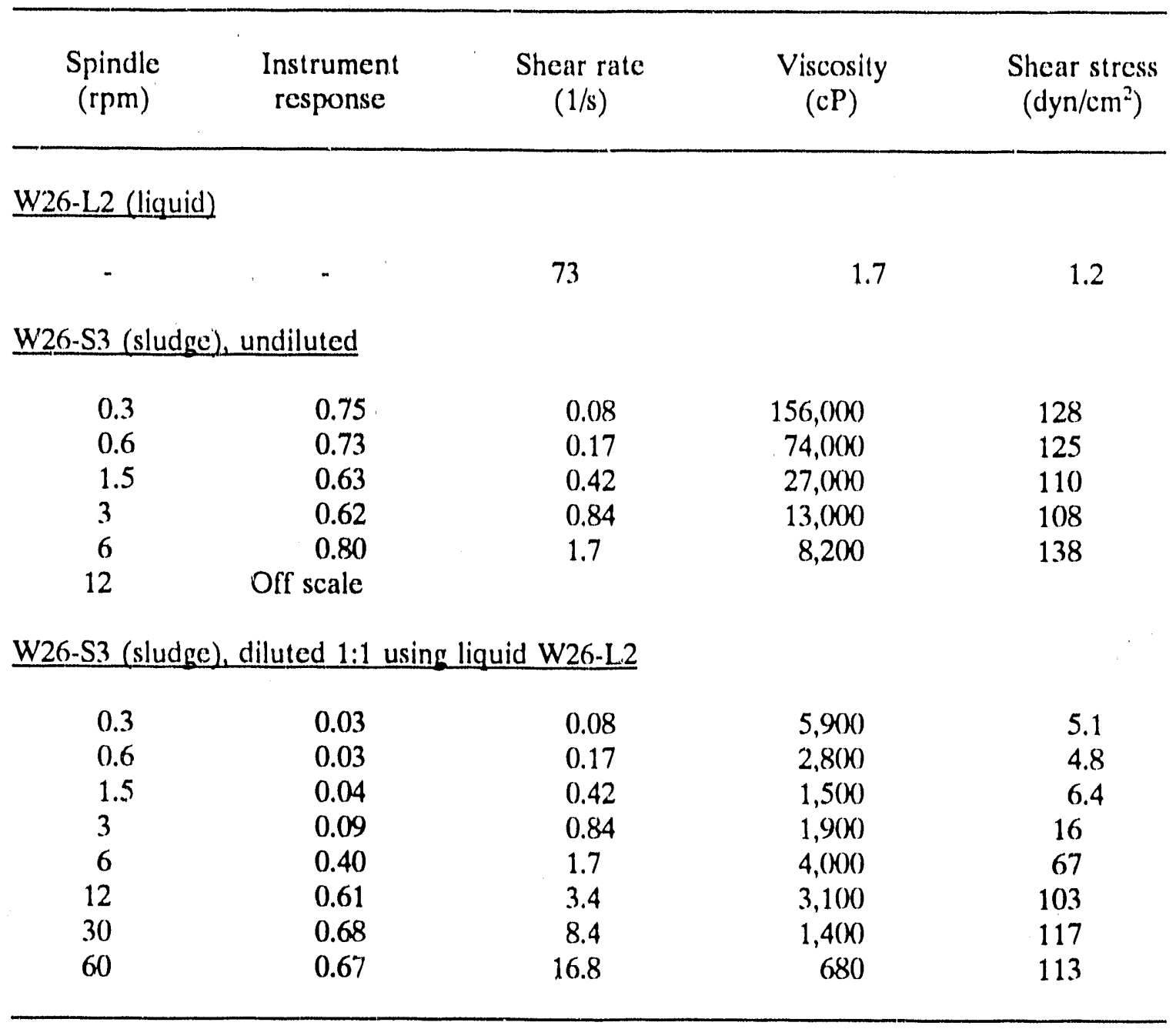

a Measured by Brookfield rotational viscometer. 
Table A.4. Viscositics of bulk liquid and sludge, tank W-28a

\begin{tabular}{ccccc}
$\begin{array}{c}\text { Spindle } \\
(\mathrm{rpm})\end{array}$ & $\begin{array}{c}\text { Instrument } \\
\text { response }\end{array}$ & $\begin{array}{c}\text { Shear rate } \\
(1 / \mathrm{s})\end{array}$ & $\begin{array}{c}\text { Viscosity } \\
(\mathrm{cP})\end{array}$ & $\begin{array}{c}\text { Shear stress } \\
\left(\mathrm{dyn} / \mathrm{cm}^{2}\right)\end{array}$ \\
\hline
\end{tabular}

W28-L.3 (liquid)

$36 \quad 2.2 \quad 0.81$

W28-S3 (sludge), undiluted ${ }^{b}$

$\begin{array}{rrlrr}0.3 & 0.19 & 0.08 & 39,000 & 32 \\ 0.6 & 0.21 & 0.17 & 21,000 & 35 \\ 1.5 & 0.30 & 0.42 & 12,000 & 51 \\ 3 & 0.48 & 0.84 & 9,800 & 82 \\ 6 & 0.90 & 1.7 & 9,200 & 150 \\ 12 & \text { Off scale } & & & \end{array}$

W28-S3 (sludge), diluted 1:1 using liquid W28-L3

$\begin{array}{rrrrr}0.3 & 0.03 & 0.08 & 6,000 & 5.0 \\ 0.6 & 0.04 & 0.17 & 4,600 & 7.4 \\ 1.5 & 0.10 & 0.42 & 4,400 & 18 \\ 3 & 0.21 & 0.84 & 3,600 & 35 \\ 6 & 0.31 & 1.7 & 3,100 & 52 \\ 12 & 0.41 & 3.4 & 2,000 & 69 \\ 30 & 0.47 & 8.4 & 950 & 79 \\ 60 & 0.51 & 16.8 & 520 & 87\end{array}$

W28-S3 (sludge), diluted 1:3 using liquid W28-L33

$\begin{array}{ccccc}0.3 & 0.02 & 0.08 & 2,800 & 2.2 \\ 0.6 & 0.02 & 0.17 & 2,000 & 3.5 \\ 1.5 & 0.07 & 0.42 & 2,900 & 12 \\ 3 & 0.08 & 0.84 & 1,700 & 15 \\ 6 & 0.10 & 1.7 & 1,100 & 19 \\ 12 & 0.12 & 3.4 & 640 & 22 \\ 30 & 0.15 & 8.4 & 300 & 26 \\ 60 & 0.17 & 16.8 & 170 & 29\end{array}$

a Measured by Brookfield rotational viscometer.

bThe undiluted sample appeared to coagulate so that solids adhered to and rotated with the spindle. Most slippage occurred within a thin liquid layer which formed between the solids mass and sample cup. Therefore, the affected measuremerits do not assay true viscosity. 
Exhibit A. Scydimentation test data for sludge from tank W-21

Dilution 1: $1.7 \mathrm{~mL}$ compacted solids $/ \mathrm{mL}$ of slurry

Liquid/slurry interface height $(\mathrm{cm})$

\begin{tabular}{|c|c|c|c|c|c|c|c|c|c|c|}
\hline $\begin{array}{l}\text { Time } \\
(\mathrm{min})\end{array}$ & 0 & 1 & 2 & 3 & 4 & 5 & 6 & 7 & 8 & 9 \\
\hline 0 & 7.6 & 7.5 & 7.4 & 7.4 & 7.3 & 7.2 & 7.2 & 7.1 & 7.0 & 6.9 \\
\hline 10 & 6.9 & 6.8 & 6.7 & 6.6 & 6.6 & 6.5 & 6.4 & 6.4 & 6.3 & 6.2 \\
\hline 20 & 6.2 & 6.1 & 6.1 & 6.1 & 5.9 & 5.9 & 5.9 & 5.8 & 5.8 & 5.7 \\
\hline 30 & 5.6 & & & & & & & & & \\
\hline
\end{tabular}

Dilution 2: $1.3 \mathrm{~mL}$ compacted sludge $/ \mathrm{mL}$ of slurry

Liquid/slurry interface height $(\mathrm{cm})$

\begin{tabular}{|c|c|c|c|c|c|c|c|c|c|c|}
\hline $\begin{array}{l}\text { Time } \\
(\min )\end{array}$ & 0 & 1 & 2 & 3 & 4 & 5 & 6 & 7 & 8 & 9 \\
\hline 0 & 7.6 & 7.5 & 7.3 & 7.3 & 7.2 & 7.1 & 7.0 & 6.9 & 6.7 & 6.6 \\
\hline 10 & 6.4 & 6.2 & 6.1 & 5.9 & 5.8 & 5.6 & 5.6 & 5.3 & 5.3 & 5.3 \\
\hline 20 & 5.1 & 5.0 & 5.0 & 4.9 & 4.7 & 4.6 & 4.6 & 4.6 & 4.4 & 4.4 \\
\hline 30 & 4.3 & & & & & & & & & \\
\hline
\end{tabular}

Dilution 3: $0.9 \mathrm{~mL}$ compacted sludge $/ \mathrm{mL}$ of slurry

Liquid/slurry interface height $(\mathrm{cm})$

\begin{tabular}{|c|c|c|c|c|c|c|c|c|c|c|}
\hline $\begin{array}{l}\text { Time } \\
(\min )\end{array}$ & 0 & 1 & 2 & 3 & 4 & 5 & 6 & 7 & 8 & 9 \\
\hline 0 & 7.6 & 7.4 & 7.0 & 6.8 & 6.6 & 6.4 & 6.2 & 5.9 & 5.6 & 5.3 \\
\hline 10 & 5.0 & 4.7 & 4.4 & 4.0 & 3.8 & 3.7 & 3.4 & 3.2 & 3.0 & 30 \\
\hline 20 & 2.9 & 2.7 & 2.7 & 2.7 & 2.6 & 2.5 & 2.4 & 2.4 & 2.3 & 2.3 \\
\hline 30 & 2.2 & & & & & & & & & \\
\hline
\end{tabular}


Exhibit A.1 (continued)

Dilution 4: $0.45 \mathrm{~mL}$ compacted sludge $/ \mathrm{mL}$ of slurry

Liquid/slurry interface height $(\mathrm{cm})$

\begin{tabular}{c|llllllllll}
\hline $\begin{array}{c}\text { Time } \\
\text { (min) }\end{array}$ & 0 & 1 & $\underline{3}$ & $\underline{3}$ & $\underline{4}$ & $\underline{5}$ & $\underline{6}$ & $\underline{7}$ & $\underline{8}$ & 9 \\
& & & & & & & & & & \\
0 & 7.6 & 7.3 & 6.9 & 6.9 & 6.5 & 6.2 & 5.8 & 5.5 & 4.9 & 4.6 \\
10 & 4.3 & 3.8 & 3.5 & 3.0 & 2.7 & 2.3 & 1.8 & 1.5 & 1.4 & 1.4 \\
20 & 1.4 & 1.3 & 1.3 & 1.2 & 1.2 & 1.2 & 1.2 & 1.2 & 1.2 & 1.2 \\
30 & 1.1 & & & & & & & & & \\
\hline
\end{tabular}

a Sludge: sample W21-S1. Liquid: sample W21-L2.

${ }^{b}$ Position of clear liquid/slurry interface (in $\mathrm{cm}$ ) from the bottom of a $10-\mathrm{mL}$ graduated mixing cylinder. 
Exhibit A.2 Sedimentation test data for sludge from tank W-23 ${ }^{a, b}$

Dilution 1: $1.0 \mathrm{~mL}$ compacted solids $/ \mathrm{mL}$ of slurry

\begin{tabular}{r|rrrrrrrrrrr}
\hline $\begin{array}{c}\text { Time } \\
(\min )\end{array}$ & \multicolumn{1}{c}{0} & 1 & 2 & 3 & 4 & 5 & 6 & 7 & 8 & 9 \\
\hline & -11.9 & 11.9 & 11.9 & 11.8 & 11.8 & 11.8 & 11.7 & 11.7 & 11.7 & 11.7 \\
0 & 11.4 & 11.4 & 11.4 & 11.4 & 11.4 & 11.4 & 11.4 & 11.4 & 11.4 & 11.4 \\
20 & 11.4 & 11.3 & 11.2 & 11.2 & 11.1 & 10.9 & 10.8 & 10.7 & 10.7 & 10.6 \\
30 & 10.5 & 10.5 & 10.2 & 10.2 & 10.1 & 10.0 & 9.9 & 9.8 & 9.8 & 9.6 \\
\hline
\end{tabular}

Dilution 2: $0.8 \mathrm{~mL}$ compacted sludge $/ \mathrm{mL}$ of slurry

\begin{tabular}{|c|c|c|c|c|c|c|c|c|c|c|}
\hline $\begin{array}{l}\text { Time } \\
(\min )\end{array}$ & 0 & 1 & 2 & 3 & 4 & 5 & 6 & 7 & 8 & 9 \\
\hline 0 & 11.9 & 11.9 & 11.9 & 11.7 & 11.7 & 11.5 & 11.4 & 11.2 & 11.1 & 10.9 \\
\hline 10 & 10.7 & 10.6 & 10.5 & 10.4 & 10.1 & 10.0 & 9.8 & 9.6 & 9.5 & 9.4 \\
\hline 20 & 9.2 & 9.0 & 8.9 & 8.8 & 8.6 & 8.4 & 8.3 & 8.1 & 8.0 & 7.9 \\
\hline 30 & 7.7 & 7.6 & 7.4 & 7.3 & 7.1 & 7.0 & 6.9 & 6.8 & 6.7 & 6.7 \\
\hline
\end{tabular}

Dilution 3: $0.6 \mathrm{~mL}$ compacted sludge/mL of slurry

\begin{tabular}{|c|c|c|c|c|c|c|c|c|c|c|}
\hline $\begin{array}{l}\text { Time } \\
(\min )\end{array}$ & 0 & 1 & 2 & 3 & 4 & 5 & 6 & 7 & 8 & 9 \\
\hline 0 & 11.9 & 11.9 & 11.8 & 11.7 & 11.4 & 11.2 & 10.9 & 10.7 & 10.5 & 10.2 \\
\hline 10 & 10.0 & 9.8 & 9.5 & 9.3 & 9.0 & 8.8 & 8.4 & 8.2 & 8.1 & 7.9 \\
\hline 20 & 7.6 & 7.5 & 7.3 & 7.1 & 6.9 & 6.8 & 6.5 & 6.4 & 6.3 & 6.2 \\
\hline 30 & 6.0 & 5.8 & 5.7 & 5.6 & 5.5 & 5.4 & 5.2 & 5.2 & 5.1 & 5.0 \\
\hline
\end{tabular}


Exhibit A.2 (continued)

Dilution 4: $0.5 \mathrm{~mL}$ compacted sludge/mL of slurry

\begin{tabular}{r|rrrrrrrrrr}
\hline $\begin{array}{c}\text { Time } \\
\text { (min) }\end{array}$ & \multicolumn{1}{|c}{0} & 1 & $\underline{3}$ & $\underline{3}$ & $\underline{4}$ & $\underline{5}$ & $\underline{6}$ & $\underline{7}$ & $\underline{8}$ & 9 \\
& & & & & & & & & & \\
0 & 11.9 & 11.9 & 11.7 & 11.4 & 10.7 & 9.9 & 9.2 & 8.4 & 8.0 & 7.4 \\
10 & 6.9 & 6.4 & 6.1 & 5.7 & 5.5 & 5.2 & 5.0 & 4.9 & 4.8 & 4.8 \\
20 & 4.6 & 4.5 & 4.4 & 4.3 & 4.3 & 4.0 & 4.0 & 3.9 & 3.8 & 3.8 \\
30 & 3.7 & 3.6 & 3.6 & 3.5 & 3.3 & 3.3 & 3.2 & 3.1 & 3.1 & 3.1 \\
\hline
\end{tabular}

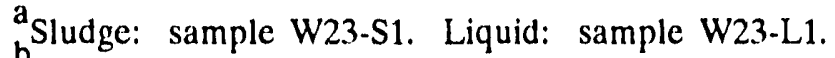

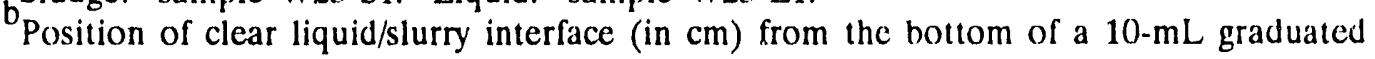
mixing cylinder. 
Exhibit A.3. Sedimentation test data for sludge from tank $\mathrm{W}-26^{\mathrm{a}, \mathrm{b}}$

Dilution 1: $1.2 \mathrm{~mL}$ compacted solids $/ \mathrm{mL}$ of slurry

\begin{tabular}{r|rrrrrrrrrrr}
\hline $\begin{array}{c}\text { Time } \\
(\mathrm{min})\end{array}$ & 0 & 1 & 2 & 3 & 4 & 5 & 6 & 7 & 8 & 9 \\
\hline 0 & 11.9 & 11.9 & 11.9 & 11.9 & 11.9 & 11.9 & 11.8 & 11.8 & 11.8 & 11.8 \\
10 & 11.8 & 11.8 & 11.8 & 11.8 & 11.8 & 11.8 & 11.8 & 11.8 & 11.7 & 11.7 \\
20 & 11.7 & 11.7 & 11.7 & 11.7 & 11.7 & 11.7 & 11.7 & 11.7 & 11.7 & 11.7 \\
30 & 11.5 & & & & & & & & & \\
\hline
\end{tabular}

Dilution 2: $0.8 \mathrm{~mL}$ compacted sludge $/ \mathrm{mL}$ of slurry

\begin{tabular}{|c|c|c|c|c|c|c|c|c|c|c|}
\hline $\begin{array}{l}\text { Time } \\
(\min )\end{array}$ & 0 & 1 & 2 & 3 & 4 & 5 & 6 & 7 & 8 & 9 \\
\hline 0 & 11.9 & 11.9 & 11.9 & 11.8 & 11.8 & 11.8 & 11.7 & 11.5 & 11.4 & 11.2 \\
\hline 10 & 11.1 & 10.8 & 10.6 & 10.4 & 10.1 & 9.9 & 9.6 & 9.5 & 9.3 & 9.0 \\
\hline 20 & 8.8 & 8.7 & 8.4 & 8.3 & 8.1 & 8.0 & 7.9 & 7.7 & 7.6 & 7.6 \\
\hline 30 & 7.5 & & & & & & & & & \\
\hline
\end{tabular}

Dilution 3: $0.6 \mathrm{~mL}$ compacted sludge/mL of slurry

\begin{tabular}{|c|c|c|c|c|c|c|c|c|c|c|}
\hline $\begin{array}{l}\text { Time } \\
(\min )\end{array}$ & 0 & 1 & 2 & 3 & 4 & 5 & 6 & 7 & 8 & 9 \\
\hline 0 & 11.9 & 11.8 & 11.7 & 11.3 & 10.9 & 10.5 & 9.9 & 9.5 & 9.0 & 8.6 \\
\hline 10 & 8.2 & 8.0 & 7.6 & 7.4 & 7.1 & 6.8 & 6.7 & 6.4 & 6.3 & 6.1 \\
\hline 20 & 6.0 & 5.8 & 5.7 & 5.6 & 5.5 & 5.5 & 5.4 & 5.4 & 5.2 & 5.2 \\
\hline 30 & 5.1 & & & & & & & & & \\
\hline
\end{tabular}


Exhibit A.3 (continucd)

Dilution 4: $0.35 \mathrm{~mL}$ compacted sludge $/ \mathrm{mL}$ of slurry

\begin{tabular}{r|rrrrrrrrrrr}
\hline $\begin{array}{c}\text { Time } \\
\text { (min) }\end{array}$ & \multicolumn{1}{c}{0} & 1 & $\underline{2}$ & $\underline{3}$ & $\underline{4}$ & $\underline{5}$ & $\underline{6}$ & $\underline{1}$ & $\underline{8}$ & $\underline{9}$ \\
& & & & & & & & & & \\
0 & 11.9 & 11.7 & 11.4 & 10.8 & 10.2 & 9.5 & 8.6 & 7.5 & 6.3 & 5.5 \\
10 & 4.9 & 4.5 & 4.3 & 4.0 & 3.9 & 3.7 & 3.6 & 3.5 & 3.5 & 3.3 \\
20 & 3.3 & 3.2 & 3.2 & 3.1 & 3.1 & 3.0 & 3.0 & 3.0 & 3.0 & 2.9 \\
30 & 2.9 & & & & & & & & & \\
\hline
\end{tabular}

a Sludge: sample W26-S3. Liquid: sample W26-L2.

$\mathrm{b}$ Position of clear liquid/slurry interface (in $\mathrm{cm}$ ) from the bottom of a 10-mL graduated mixing cylinder. 
Exhibit A.4. Sodimentation test data for sludge from tank $W-28^{\mathrm{a}, \mathrm{b}}$

Dilution 1: $0.65 \mathrm{~mL}$ compacted solids/mL of slurry

\begin{tabular}{|c|c|c|c|c|c|c|c|c|c|c|}
\hline $\begin{array}{l}\text { Time } \\
\text { (min) }\end{array}$ & 0 & 1 & 2 & 3 & 4 & 5 & 6 & 7 & 8 & 9 \\
\hline 0 & 11.9 & 11.9 & 11.9 & 11.9 & 11.8 & 11.7 & 11.4 & 11.4 & 11.1 & 10.8 \\
\hline 10 & 10.4 & 10.1 & 9.9 & 9.5 & 9.2 & 9.0 & 8.8 & 8.6 & 8.3 & 8.2 \\
\hline 20 & 8.0 & 7.9 & 7.6 & 7.4 & 7.3 & 7.1 & 6.9 & 6.7 & 6.4 & 6.3 \\
\hline 30 & 6.3 & & & & & & & & & \\
\hline
\end{tabular}

Dilution 2: $0.45 \mathrm{~mL}$ compacted sludge $/ \mathrm{mL}$ of slurry

\begin{tabular}{|c|c|c|c|c|c|c|c|c|c|c|}
\hline $\begin{array}{l}\text { Time } \\
(\min )\end{array}$ & 0 & 1 & 2 & 3 & 4 & 5 & 6 & 7 & 8 & 9 \\
\hline 0 & 11.9 & 11.9 & 11.9 & 11.9 & 11.7 & 11.2 & 10.8 & 10.5 & 10.0 & 9.5 \\
\hline 10 & 8.9 & 8.4 & 81 & 7.6 & 7.1 & 6.9 & 6.7 & 6.4 & 6.2 & 6.1 \\
\hline 20 & 5.8 & 5.6 & 5.5 & 5.2 & 5.1 & 5.0 & 4.8 & 4.6 & 4.5 & 4.5 \\
\hline 30 & 4.4 & & & & & & & & & \\
\hline
\end{tabular}

Dilution 3: $0.31 \mathrm{~mL}$ compacted sludge $/ \mathrm{mL}$ of slurry

\begin{tabular}{|c|c|c|c|c|c|c|c|c|c|c|}
\hline $\begin{array}{l}\text { Time } \\
(\min )\end{array}$ & 0 & 1 & 2 & 3 & 4 & 5 & 6 & 7 & 8 & 9 \\
\hline 0 & 11.9 & 11.9 & 11.9 & 11.9 & 11.8 & 11.4 & 11.3 & 11.2 & 9.5 & 8.3 \\
\hline 10 & 6.5 & 5.2 & 4.5 & 3.8 & 3.6 & 3.3 & 3.2 & 3.1 & 3.0 & 3.0 \\
\hline 20 & 3.0 & 2.9 & 2.9 & 2.7 & 2.6 & 2.6 & 2.6 & 2.6 & 2.6 & 2.5 \\
\hline 30 & 2.5 & & & & & & & & & \\
\hline
\end{tabular}

Dilution 4: $0.20 \mathrm{~mL}$ compacted sludge/mL of slurry

Note: This slurry was too dilute for solids to coagulate efficiently. The clear liquid/slurry interface was not visible, but the system appeared instead as a cloudy liquid which became less turbid with time.

\footnotetext{
${ }^{a}$ Sludge: sample W21-S1. Liquid: sample W21-L2.

bosition of clear liquid/slurry interface (in $\mathrm{cm}$ ) from the bottom of a $10-\mathrm{mL}$ graduated mixing cylinder.
} 
APPENDIX B

CALCULATIONAL MODEL USED TO DETERMINE

DENSITY AND SOLIDS VALUES 


\section{APPENDIX B}

\section{CALCULATIONAL MODEL USED TO DETERMINE DENSITY AND SOLIDS VALUES}

Two portions of each sludge sample were required for a set of measurements. The first portion (about $5 \mathrm{~g}$ ) was placed into a tared, graduated $15-\mathrm{mL}$ centrifuge tube and weighed. The sludge was centrifuged for $15 \mathrm{~min}$ at high speed before reading the total volume and calculating the bulk density:

$$
\text { Bulk density }=\frac{\text { Wet mass } 1}{\text { Wet volume } 1}
$$

The separated interstitial liquid was drawn off from the centrifuged sample using a transfer pipet, then filtered through a $0.45-\mu \mathrm{m}$ filter. One milliliter of the filtered solution was weighed to determine the interstitial liquid density:

$$
\text { Liquid density }=\frac{\text { Solution mass }}{1 \mathrm{~mL}} \text {. }
$$

After being weighed, the $1-\mathrm{mL}$ sampie was dried at $110 \pm 5^{\circ} \mathrm{C}$ for $16 \pm 1 \mathrm{~h}$ and was then reweighed to determine loss of water and other volatiles:

Water loss (1 mL liquid) = Solution mass - Residue mass.

A second portion (about $1 \mathrm{~g}$ ) of the original sludge was taken. This portion was placed into a tared $10-\mathrm{mL}$ beaker and weighed. The sludge was dried at $110 \pm 5^{\circ} \mathrm{C}$ for $16 \pm 1 \mathrm{~h}$, then reweighed to determine the total solids content and loss of water and other volatiles:

$$
\text { Total solids }=\frac{\text { Dry mass } 2}{\text { Wet mass } 2}
$$

Water loss (sludge) $=$ Wet mass $2-$ Dry mass 2 . 
The dissolved solids content was calculated from the solution residue mass, the water losses from sludge and solution, and the wet sludge mass:

$$
\text { Dissolved solids }=\frac{\text { Residue mass }}{\text { wet mass } 2} \times \frac{\text { water loss (sludge) }}{\text { Water loss (1 mL I iquid) }}
$$

The mass of interstitial liquid actually present in the second sludge portion is calculated from the liquid density and the ratio of water lost in drying the sludge to that lost in drying the liquid:

$$
\text { Liquid mass }=\text { Liquid density } \times \frac{\text { water loss (sludge) }}{\text { water loss }(1 \mathrm{~mL} \text { liquid) }} .
$$

The undissolved solids content was calculated by difference, as follows:

Undissolved solids = Total solids - Dissolved solids.

The undissolved solids density was also calculated as the ratio of differences in mass and volume:

$$
\text { Floc density }=\frac{\text { Wet mass } 2-\text { Liquidmass }}{\frac{\text { wet mass } 2}{\text { bulk density }}-\frac{\text { water loss (sludge })}{\text { water loss (1 mL liquid) }}} \text {. }
$$



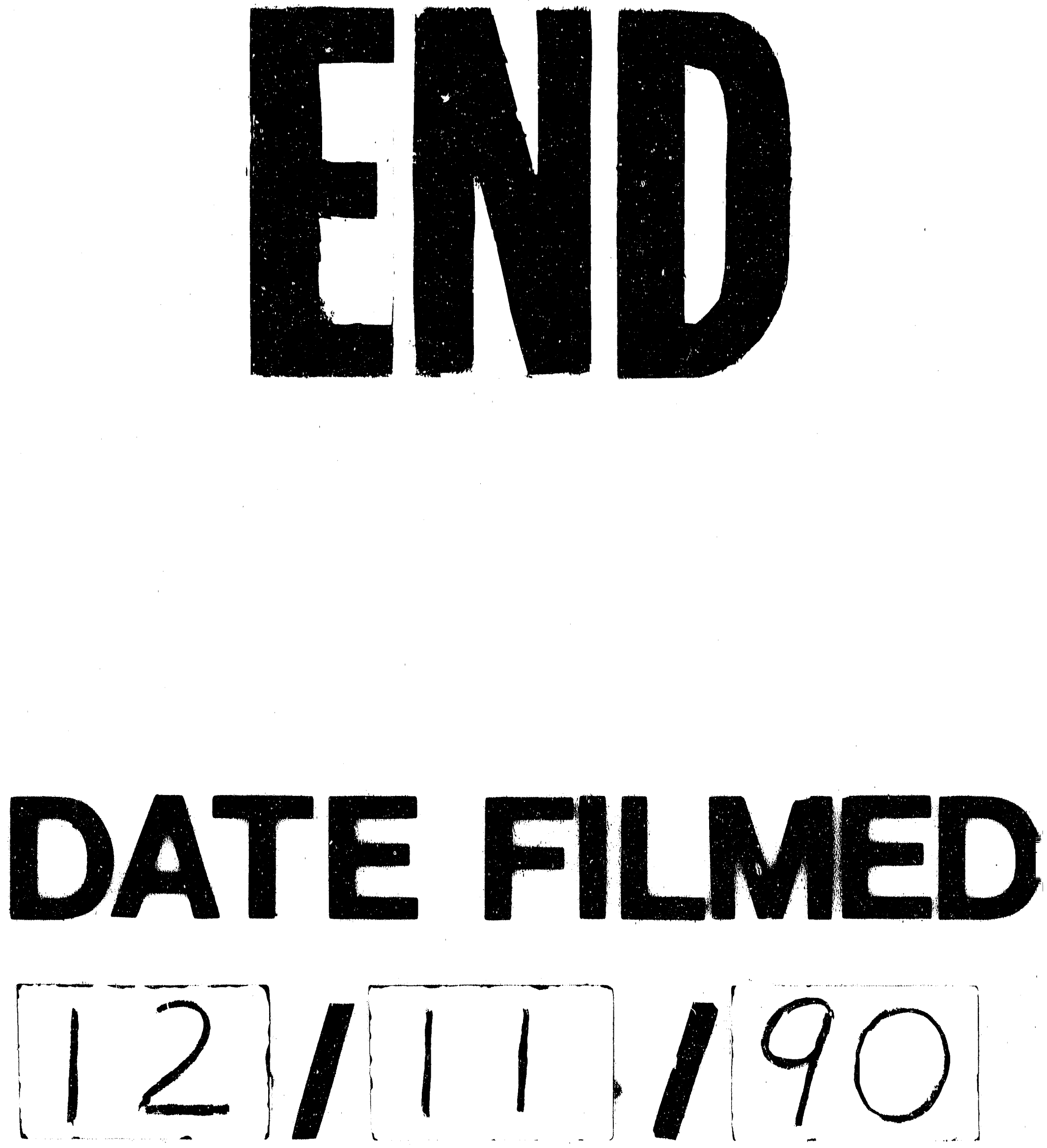
